2010

\title{
Variations in Synechococcus Cell Quotas of Phosphorus, Sulfur, Manganese, Iron, Nickel, and Zinc within Mesoscale Eddies in the Sargasso Sea
}

\author{
Benjamin S. Twining \\ Daliangelis Nunez-Milland \\ Stefan Vogt \\ Rodney S. Johnson \\ Peter N. Sedwick \\ Old Dominion University, Psedwick@odu.edu
}

Follow this and additional works at: https://digitalcommons.odu.edu/oeas_fac_pubs
Part of the Biogeochemistry Commons, Oceanography Commons, and the Other Oceanography and Atmospheric Sciences and Meteorology Commons

\section{Repository Citation}

Twining, Benjamin S.; Nunez-Milland, Daliangelis; Vogt, Stefan; Johnson, Rodney S.; and Sedwick, Peter N., "Variations in Synechococcus Cell Quotas of Phosphorus, Sulfur, Manganese, Iron, Nickel, and Zinc within Mesoscale Eddies in the Sargasso Sea" (2010). OEAS Faculty Publications. 102.

https://digitalcommons.odu.edu/oeas_fac_pubs/102

\section{Original Publication Citation}

Twining, B.S., Nunez-Milland, D., Vogt, S., Johnson, R.S., \& Sedwick, P.N. (2010). Variations in Synechococcus cell quotas of phosphorus, sulfur, manganese, iron, nickel, and zinc within mesoscale eddies in the sargasso sea. Limnology and Oceanography, 55(2), 492-506. doi: 10.4319/lo.2009.55.2.0492 


\title{
Variations in Synechococcus cell quotas of phosphorus, sulfur, manganese, iron, nickel, and zinc within mesoscale eddies in the Sargasso Sea
}

\author{
Benjamin S. Twining, ${ }^{\mathrm{a}, 1, *}$ Daliangelis Nuñez-Milland, ${ }^{\text {a }}$ Stefan Vogt, ${ }^{\mathrm{b}}$ Rodney S. Johnson, ${ }^{\mathrm{c}}$ and \\ Peter N. Sedwick ${ }^{\mathrm{d}}$ \\ a Department of Chemistry and Biochemistry, University of South Carolina, Columbia, South Carolina \\ b Advanced Photon Source, Argonne National Laboratory, Argonne, Illinois \\ c Bermuda Institute of Ocean Sciences, St. Georges, Bermuda \\ dDepartment of Ocean, Earth and Atmospheric Sciences, Old Dominion University, Norfolk, Virginia
}

\begin{abstract}
The quotas of P, S, Mn, Fe, Ni, and Zn in individual Synechococcus cells collected from the surface and deep chlorophyll maximum (DCM) layer of three mesoscale eddies in the Sargasso Sea were measured using synchrotron X-ray fluorescence microscopy. Cells in a mode-water eddy had significantly higher P (57 \pm 10 amol) and $\mathrm{Mn}(28 \pm 7 \mathrm{zmol})$ cell quotas than cells collected from a cyclone $(22 \pm 2 \mathrm{amol}$ and $10 \pm 1 \mathrm{zmol}$, respectively $)$ or anticyclone $(25 \pm 3 \mathrm{amol}$ and $18 \pm 3 \mathrm{zmol}$, respectively). Conversely, $\mathrm{Ni}$ and $\mathrm{Zn}$ quotas were significantly higher in the cells from the anticyclone (92 \pm 19 and $561 \pm 150 \mathrm{zmol}$, respectively) than in cells from the cyclonic ( $25 \pm 4$ and $35 \pm 7 \mathrm{zmol}$, respectively) or mode-water $(30 \pm 9$ and $21 \pm 8 \mathrm{zmol}$, respectively) eddies. These changes may reflect biochemical responses (e.g., production of urease and alkaline phosphatase) to gradients in inorganic $\mathrm{N}$ and $\mathrm{P}$ supplies. Cellular quotas of $\mathrm{Fe}(111 \pm 17 \mathrm{zmol}$ in the cyclone) and $\mathrm{S}(52 \pm 6$ amol in the cyclone) did not vary significantly among eddies despite two- to threefold higher dissolved and particulate $\mathrm{Fe}$ concentrations in the anticylone. Cells collected from 10-m depth contained approximately $80 \%$ more Ni and $\mathrm{S}$ than cells collected from the DCM, potentially reflecting cell responses to heightened oxidative stress. Depthrelated trends varied by eddy for the other elements. Cellular $\mathrm{P}$ and $\mathrm{Zn}$ varied significantly during repeated samplings of the cyclone, with quotas of both elements dropping as bulk chlorophyll biomass in the DCM increased. These data demonstrate the dynamic responses of phytoplankton elemental composition to physical and chemical environmental gradients.
\end{abstract}

Transition metals play numerous critical roles in the metabolism of marine phytoplankton, and their availability can exert important controls on algal community structure, physiology, production, and the associated cycling of carbon and nutrient elements. Iron appears to play the most significant role as a limiting trace nutrient for oceanic phytoplankton, but other metals may also influence phytoplankton function in certain areas of the ocean. For example, $\mathrm{Cu}$ availability can affect species composition as both a toxin and a micronutrient (Mann et al. 2002), and $\mathrm{Zn}$ availability may limit the production of carbonic anhydrase or alkaline phosphatase by diatoms and coccolithophores in the oligotrophic ocean (Morel et al. 1994; Shaked et al. 2006). As potential biochemical substitutes for $\mathrm{Zn}$-based metalloenzymes, $\mathrm{Co}$ and $\mathrm{Cd}$ could also influence phytoplankton composition and metabolism in certain environments (Cullen et al. 1999; Saito et al. 2004). In addition, there are a number of important linkages between the availability of trace metals and the uptake and assimilation of the macronutrient elements (DeBaar et al. 1997; Hutchins and Bruland 1998).

\section{*Corresponding author: btwining@bigelow.org}

${ }^{1}$ Present address: Bigelow Laboratory for Ocean Sciences, W. Boothbay Harbor, Maine
Much of our knowledge about the interactions of metals and plankton comes from laboratory studies of phytoplankton grown under controlled physical and chemical conditions. This approach has yielded important information regarding metal uptake kinetics, cellular metal quotas, and the interactions between metals, ligands, and biological availability. However, linking such information to the natural system is challenging in part because of the uncharacterized nature of natural metal-binding ligands and the effects of covarying environmental conditions such as light, macronutrient concentrations, metal concentrations, and metal speciation. Measurements of metal uptake and cellular metal concentrations in natural environments are often complicated by the extremely low metal concentrations in natural waters, the uncertain speciation of dissolved metals, and the heterogeneous particle assemblages that can confound the interpretation of bulk particulate metal concentrations. Efforts to measure the elemental composition of plankton have historically focused on larger eukaryotic groups that can be isolated by filtration (Martin and Knauer 1973; Collier and Edmond 1984), and there have been few studies of the cellular composition of natural populations of cyanobacteria. Indeed, there are as yet no direct measurements of cellular metal quotas for strains of Synechococcus or Prochlorococcus, both of which are prolific in the tropical and subtropical oceans. However, new analytical approaches now allow for the analysis of individual phyto- 


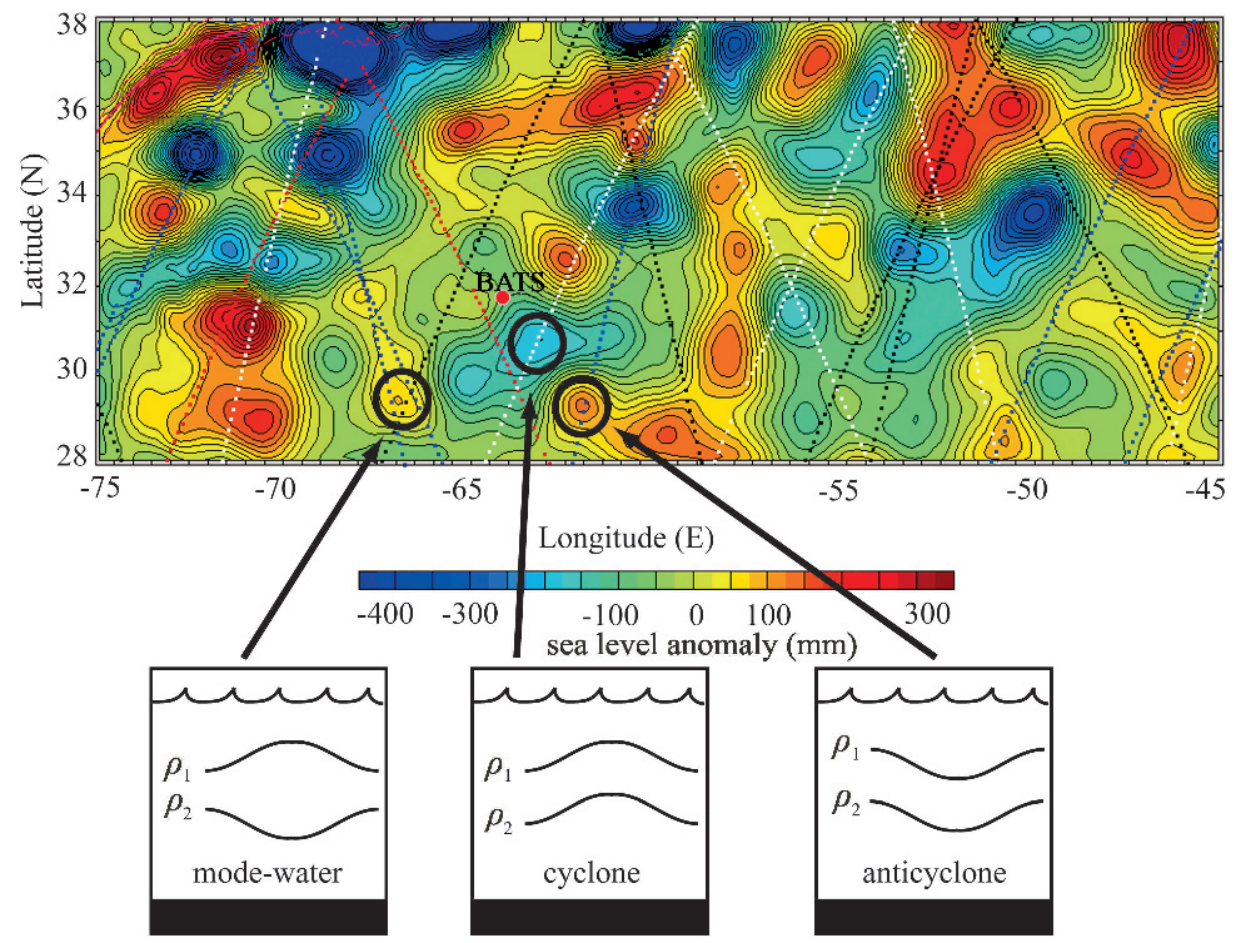

Fig. 1. Objective analysis of sea-level anomalies showing the three eddies sampled (image provided by Dennis McGillicuddy and Valery Kosnyrev of Woods Hole Oceanographic Institution) and their respective isopycnal displacements (modified from McGillicuddy et al. 2007). Two density surfaces are shown: the seasonal $\left(\rho_{1}\right)$ and permanent $\left(\rho_{2}\right)$ thermoclines. Satellite ground tracks are shown for the satellites used to collect the sea-level data.

plankton cells, thus dramatically improving our understanding of the roles of metals in phytoplankton metabolism as well as the marine biogeochemistry of trace metals (Twining et al. 2008).

Mesoscale eddies are an important component of surface circulation in much of the ocean and may dominate shortterm surface circulation in areas such as the subtropical western North Atlantic (McGillicuddy et al. 1998, 2007; Steinberg et al. 2001). Indeed, a number of recent studies have demonstrated the importance of these features in regulating biogeochemical fluxes and primary production in the oligotrophic ocean (Benitez-Nelson and McGillicuddy 2008). In the subtropical surface ocean, mesoscale eddies are typically $\sim 100 \mathrm{~km}$ in diameter and effect isopycnal displacements of tens to hundreds of meters; they are thus readily identified from satellite sea-level altimetry and hydrographic transects. Figure 1 illustrates three types of mesoscale eddies that are commonly observed in the western subtropical North Atlantic (Sargasso Sea): cyclonic eddies, which result in uplift of the permanent and seasonal thermoclines; anticyclonic eddies, which result in the depression of the permanent and seasonal thermoclines; and mode-water eddies, which are characterized by a thick layer of subtropical mode water that uplifts the seasonal thermocline and depresses the permanent thermocline (McGillicuddy et al. 1999). The passage of eddies can result in the introduction of nutrients into the euphotic zone (McNeil et al. 1999), and such events may constitute a significant annual source of nutrients to surface waters in oligotrophic systems such as the Sargasso Sea (McGillicuddy et al. 1998). Mode-water eddies are thought to be particularly effective in supplying nutrients to the euphotic zone, and these features can display significantly elevated phytoplankton biomass relative to surrounding waters (Benitez-Nelson et al. 2007; McGillicuddy et al. 2007).

Much of the research focusing on the biogeochemistry of mesoscale eddies has been conducted in the Sargasso Sea in the area of the Bermuda Atlantic Time-Series Study (BATS) (McGillicuddy and Robinson 1997; McNeil et al. 1999; McGillicuddy et al. 2007). Surface waters in this part of the North Atlantic Subtropical Gyre are extremely oligotrophic during the summer and fall, when dissolved inorganic nitrogen and phosphorous concentrations reach nanomolar levels (Steinberg et al. 2001). The area receives significant atmospheric $\mathrm{Fe}$ inputs during the summer (Sedwick et al. 2005), and Fe is not thought to limit the growth of phytoplankton during the summer and fall. However, $\mathrm{Zn}$ and Co concentrations are extremely low in surface waters throughout the year (Saito and Moffett 2002; Jakuba et al. 2008), which may limit the utilization of organic P by phytoplankton. Prokaryotic picoplankton dominate the autotrophic community during much of the year, with Prochlorococcus typically most concentrated near the base of the euphotic zone in the deep chlorophyll maximum (DCM) and Synechococcus more abundant at shallower depths (Olson et al. 1990a; DuRand et al. 2001).

Although typically not as abundant as Prochlorococcus, Synechococcus is a ubiquitous and rapidly growing 
Table 1. Number, location, eddy type, and sampling depths $(\mathrm{m})$ for each station. Concentrations of chlorophyll $a\left(\mu \mathrm{g} \mathrm{L}^{-1}\right)$ are presented for $10 \mathrm{~m}$ and the DCM. Also shown are measured concentrations of dissolved $\mathrm{Fe}\left(\mathrm{dFe}\right.$; nmol L $\left.\mathrm{L}^{-1}\right)$, particulate Fe (pFe; nmol L-1), and particulate P $(\mathrm{pP} ;$ nmol L-1) as well as the number of Synechococcus cells analyzed with $\mathrm{SXRF}$. nd $=$ not determined.

\begin{tabular}{|c|c|c|c|c|c|c|c|c|c|c|}
\hline Station & Eddy & Date & Latitude & Longitude & Depth & Chl $a$ & $\mathrm{dFe}$ & $\mathrm{pFe}$ & $\mathrm{pP}$ & Cells analyzed \\
\hline & & & & & 90 & 0.23 & 0.09 & 0.47 & 7.8 & 0 \\
\hline $\mathrm{K} 2$ & Mode-water & 09 Jul 07 & $29^{\circ} 02.2^{\prime} \mathrm{N}$ & $66^{\circ} 44.3^{\prime} \mathrm{W}$ & 10 & 0.02 & 0.41 & nd & nd & 0 \\
\hline \multirow[t]{2}{*}{$\mathrm{K} 3$} & Cyclonic & $10 \mathrm{Jul} 07$ & $30^{\circ} 40.7^{\prime} \mathrm{N}$ & $62^{\circ} 38.7^{\prime} \mathrm{W}$ & 10 & 0.03 & 0.45 & nd & nd & 10 \\
\hline & & & & & 90 & 0.31 & 0.14 & nd & nd & 22 \\
\hline K4 & Cyclonic & 11 Jul 07 & $30^{\circ} 36.4^{\prime} \mathrm{N}$ & $62^{\circ} 32.5^{\prime} \mathrm{W}$ & 10 & 0.02 & 0.41 & 0.82 & 6.0 & 10 \\
\hline & & & & & 140 & 0.19 & 0.18 & 0.58 & 6.8 & 27 \\
\hline
\end{tabular}

autotroph in the oligotrophic oceans and may thus play an important role in the biogeochemical cycling of these regions (Waterbury et al. 1986).

In order to understand and model the biogeochemical and ecological function of Synechococcus, there is a need for quantitative information on the elemental requirements and cellular composition of this organism. In this paper, we report measurements of the cellular quotas of $\mathrm{P}, \mathrm{S}, \mathrm{Mn}, \mathrm{Fe}$, $\mathrm{Ni}$, and $\mathrm{Zn}$ in Synechococcus cells collected from surface waters and the DCM in three different types of mesoscale eddies in the Sargasso Sea. These data comprise the first directly measured cellular metal quotas for Synechococcus collected from the open ocean. We observed significant differences in the element composition of cells from the three eddies, which we interpret to be indicative of differences in nutrient supply and utilization among these eddies.

\section{Methods}

Location and sampling of mesoscale eddies-Three mesoscale eddies were sampled in the Sargasso Sea south of the BATS study area $\left(29-31^{\circ} \mathrm{N}, 61-67^{\circ} \mathrm{W}\right)$ during a cruise in July 2007 aboard R/V Atlantis Explorer (Table 1). The eddies were initially identified from satellite-derived sea-level anomalies (McGillicuddy et al. 2007; Fig. 1), and their identity as either cyclonic, anticyclonic, or modewater eddies was confirmed from water column hydrographic surveys deploying a CTD-rosette and expendable bathythermographs (Fig. 2). Water column samples for bulk and single-cell metal analyses were collected using 5or 30-liter modified Niskin-X samplers deployed on a Kevlar line using stringent trace-metal clean techniques (Sedwick et al. 2005). All samples for synchrotron X-ray

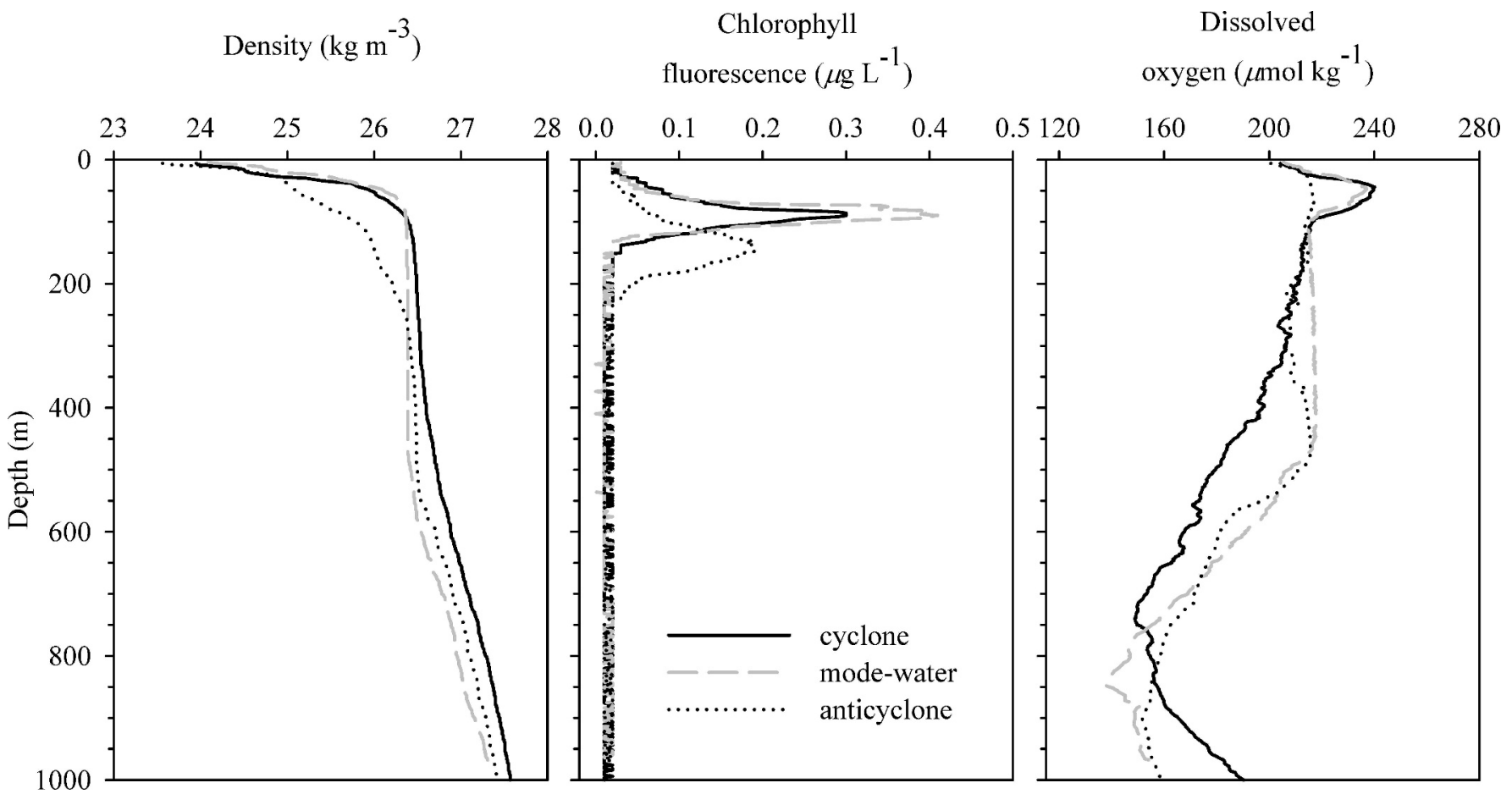

Fig. 2. Representative depth profiles of density $\left(\mathrm{kg} \mathrm{m}^{-3}\right)$, chlorophyll fluorescence $\left(\mu \mathrm{g} \mathrm{L}^{-1}\right)$, and dissolved oxygen $\left(\mu \mathrm{mol} \mathrm{kg}^{-1}\right)$ for the three eddies. 
fluorescence (SXRF) were collected from either surface waters (10-m depth) or the DCM (85-90-m depth in the cyclonic and mode-water eddies, 140-m depth in the anticyclonic eddy; Fig. 2). The water samplers were transferred to a Class-100 clean van or shipboard clean bubble prior to subsampling.

Sample processing and SXRF analysis-All SXRF sample processing was conducted in a Class-100 laminarflow hood using acid-washed plasticware following the protocols of Twining et al. (2004b). Unfiltered water samples were withdrawn from the samplers and immediately subsampled for SXRF analysis and for cell enumeration using epifluoresence microscopy. The SXRF samples were immediately preserved in trace metal-clean glutaraldehyde $(0.25 \%$ final concentration) and centrifuged onto 200-mesh gold transmission electron microscopy grids coated with $\mathrm{C}$ and Formvar films. Trace metal contaminants were removed from the glutaraldehyde with Dowex resin prior to use (Twining et al. 2003). The grids were then briefly rinsed in ultrapure deionized water and air dried in the dark under the Class-100 laminar-flow hood. The mounted cells were imaged within $24 \mathrm{~h}$ using light microscopy (Nomarski optics) and epifluorescence (blue excitation: $480 \mathrm{~nm}$ ) microscopy. Cells were also collected onto black $0.2-\mu \mathrm{m}$ polycarbonate membranes and mounted onto glass slides with immersion oil to enable quantitative cells counts via standard epifluorescence microsocopy techniques (MacIsaac and Stockner 1993).

Cell elemental quotas were measured at the Advanced Photon Source using the hard X-ray microprobe at beamline 2-ID-E following previously described protocols (Twining et al. 2003, 2004a). The cells were analyzed during visits in November 2007 and April 2008. A monochromatic $10 \mathrm{keV}$ X-ray beam was focused to approximately $0.3 \mu \mathrm{m}$ using a Fresnel zone plate with a $10-\mathrm{cm}$ focal length. Individual Synechococcus cells that had been previously identified by their size, shape, and autofluorescence characteristics (see further discussion below) were scanned in two-dimensional raster fashion using $0.2-\mu \mathrm{m}$ step sizes. Dwell times were varied between 4 and $9 \mathrm{~s}$ per pixel in response to changing beam flux conditions to ensure adequate fluorescence photon counts.

SXRF data analysis-Element quantification was performed as described in Twining et al. (2004a). Briefly, spectra from the pixels representing the target cells were averaged and fit with a custom fitting software package (MAPS; Vogt 2003). Spectra were also averaged for a background region near the cell representing the FormvarC film substrate. Peak areas for the background were subtracted from cellular peak areas. Average background corrections for each element were $23 \%, 14 \%, 45 \%, 44 \%$, $32 \%$, and $22 \%$ for $\mathrm{P}, \mathrm{S}, \mathrm{Mn}, \mathrm{Fe}, \mathrm{Ni}$, and $\mathrm{Zn}$, respectively. Areal elemental concentrations were calculated for each sample from National Institute of Standards and Technology (NIST) thin-film standard reference materials (1832 and 1833). Conversion factors for $\mathrm{P}, \mathrm{S}$, and $\mathrm{Ni}$ (which are not present in the NIST standards) were calculated by interpolation from the conversion factors for $\mathrm{Si}, \mathrm{K}, \mathrm{Ca}, \mathrm{Ti}$, $\mathrm{V}, \mathrm{Cr}, \mathrm{Mn}, \mathrm{Fe}, \mathrm{Co}, \mathrm{Cu}$, and $\mathrm{Zn}$ when plotted as a function of the theoretical fluorescence yield $\left(r^{2}=0.996\right.$; D. NuñezMilland unpubl.).

Elemental quotas were log-transformed prior to statistical analysis to normalize the data and stabilize variance. To identify outliers, quotas were fit to an ANOVA model that included eddy type and sample depth (combined to form eight unique classes) as effects. Model analyses were made using JMP software (v. 6.0, SAS Institute). Jackknifed studentized residuals of this model were calculated, and all observations with values $>3$ were excluded from further analysis (Sokal and Rohlf 1995; Baines et al. in press). After the outlying cell data were excluded, the model was refit and the process repeated iteratively until outliers were no longer identified. Using this approach, fewer than five cell quotas (less than $4 \%$ of the total) were removed from each element data set. Differences in element quotas related to depth of collection (10 m vs. DCM) and eddy type were examined with a two-way ANOVA model that used both variables as effects.

Bulk dissolved $\mathrm{Fe}$, particulate $\mathrm{Fe}$ and $\mathrm{P}$, and macronutrient concentrations - Concentrations of dissolved $\mathrm{Fe}$ and particulate $\mathrm{Fe}$ and $\mathrm{P}$ were also measured in each eddy, and these are presented here to provide context for the interpretation of the Synechococcus element quotas measured with SXRF. Dissolved Fe samples were collected, processed, and analyzed with spectrophotometric flow injection analysis as per Sedwick et al. (2005), with the exception that samples were filtered through $0.45-\mu \mathrm{m}$ Pall Supor Acropak cartridges (except surface pole samples, which were filtered through $0.4-\mu \mathrm{m}$ polycarbonate membranes), and acidified to $\mathrm{pH}$ 1.7. Accuracy of this analytical techniqued has been verified by analysis of dissolved $\mathrm{Fe}$ in the $\mathrm{SAFe}$ reference seawater samples $\mathrm{S} 1$ and D2, for which our measured values of $0.11 \pm$ $0.01 \mathrm{nmol} \mathrm{L}^{-1}(n=15)$ and $0.97 \pm 0.06 \mathrm{nmol} \mathrm{L}^{-1}(n=$ 14) compare well with consensus values of $0.097 \pm$ $0.043 \mathrm{nmol} \mathrm{L}-1$ and $0.91 \pm 0.17 \mathrm{nmol} \mathrm{L}^{-1}$, respectively (Johnson et al. 2007).

Particulate samples for measurements of $\mathrm{Fe}$ and $\mathrm{P}$ were collected from the same 30-liter Niskin-X sample bottles as the SXRF samples. Particles $(>0.6 \mu \mathrm{m})$ were collected under a vacuum of $<0.2$ bar onto acid-leached $25-\mathrm{mm}$ polycarbonate membranes mounted in a polysulfone filter tower contained within a Class-100 laminarflow hood. Typically, 1 liter of seawater was filtered. Filters were then stored at $-20^{\circ} \mathrm{C}$ until analysis. Filters were digested in a mixture of concentrated $\mathrm{HNO}_{3}$ and HF acids and analyzed with inductively coupled plasma mass spectrometry following the protocols of Cullen et al. (2001). The Fe and P contents of acid-leached filter blanks $(n=9)$ were measured at 319 and $700 \mathrm{pmol}$ filter ${ }^{-1}$, respectively.

Dissolved inorganic nitrate and phosphate concentrations were measured in filtered, frozen seawater samples at the Bermuda Institute for Ocean Science using methods employed for the BATS program, which are modified from the Joint Global Ocean Flux Study autoanalyzer tech- 


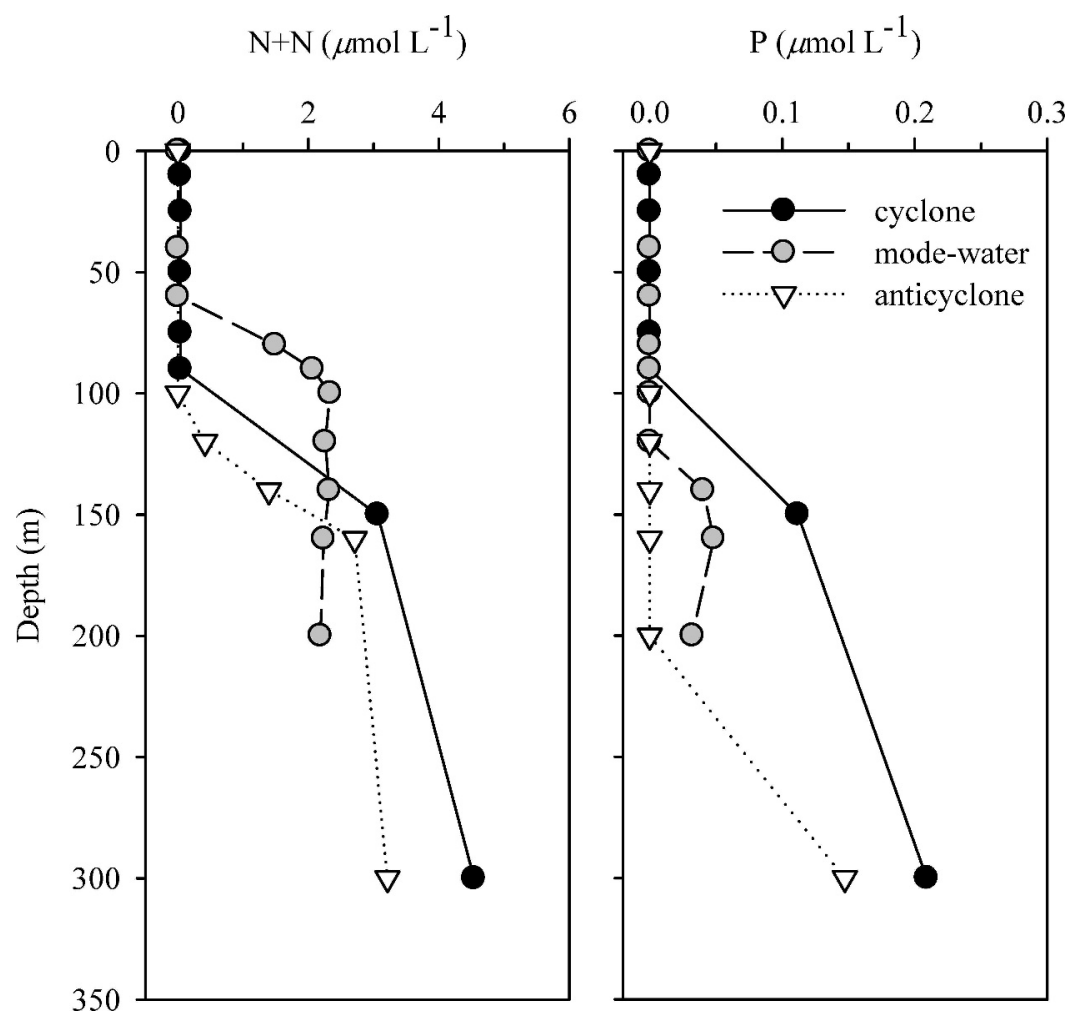

Fig. 3. Representative depth profiles of nitrate + nitrite $\left(\mathrm{N}+\mathrm{N} ; \mu \mathrm{mol} \mathrm{L}{ }^{-1}\right)$ and phosphate $(\mathrm{P} ; \mu \mathrm{mol} \mathrm{L}-1)$ for the three eddies. Nitrite concentrations were negligible $(<5 \%)$ compared to nitrate concentrations in each sample.

niques (Knap et al. 1993), with detection limits of $40 \mathrm{nmol} \mathrm{L}-1$ and $30 \mathrm{nmol} \mathrm{L}-1$ respectively.

\section{Results}

Eddy characteristics - The three eddies sampled during the study showed distinct physical and biogeochemical signatures (Fig. 2). Both the cyclonic and the mode-water eddies had shallower seasonal thermoclines than observed in the anticyclonic eddy, while the permanent thermocline was depressed in the mode-water and anticyclonic eddies relative to the cyclonic eddy. The uplifted pycnoclines resulted in increased supplies of macronutrients from below the thermocline. Both nitrate and phosphate were elevated in the cyclonic and mode-water eddies at $\sim 125 \mathrm{~m}$ relative to the anticyclonic eddy (Fig. 3). Presumably as a result, chlorophyll biomass within the DCM was approximately $50 \%$ and $100 \%$ higher in the cyclonic and mode-water eddies, respectively, than in the anticyclonic eddy. In addition, dissolved oxygen near the DCM was enhanced in the cyclone and mode-water eddies, indicating higher primary productivity.

Cellular element quotas-The elemental contents of 118 cells collected from the three eddies were analyzed with SXRF. False-color maps of P, S, Mn, Fe, Ni, and Zn for a representative cell are shown in Fig. 4. The elements are clearly visible in the cells above background concentrations in the supporting $\mathrm{C}$ and Formvar film. Geometric mean cellular quotas of these elements for cells collected from two depths in the three eddies are presented in Table 2. Phosphorus and S can each be utilized as a proxy of cellular biomass, and both elements were present in attomole $\left(10^{-18} \mathrm{~mol}\right)$ quantities in individual cells. The transition metals $\mathrm{Mn}, \mathrm{Fe}, \mathrm{Ni}$, and $\mathrm{Zn}$ were approximately 1000 -fold less abundant in the cells, with metal quotas ranging from 8 to 1138 zeptomole $\left(10^{-21} \mathrm{~mol}\right)$ per cell. In general, the mean $\mathrm{Mn}, \mathrm{Ni}$, and $\mathrm{Zn}$ quotas were lower than mean $\mathrm{Fe}$ quotas (8-58 zmol cell-1 compared to $81-224 \mathrm{zmol} \mathrm{cell}^{-1}$, respectively), with the exception of $\mathrm{Ni}$ and $\mathrm{Zn}$ quotas in the anticyclonic eddy (64-1138 $\mathrm{zmol}^{\mathrm{cell}}{ }^{-1}$ at the two depths), which exceeded corresponding Fe quotas.

Significant differences are observed in the elemental content of cells collected from the three different eddies. Least-square geometric means for each eddy are presented in Fig. 5. Calculated from the ANOVA, least-square means are an attempt to statistically separate differences related to eddy type and sampling depth. The largest eddy effects are seen with $\mathrm{P}, \mathrm{Ni}$, and $\mathrm{Zn}$. Phosphorus quotas varied significantly between eddies $(p<0.0001)$, with cells from the cyclonic eddy having the lowest quotas and cells from the mode-water eddy containing approximately 2.5-fold more $\mathrm{P}$. By contrast, both $\mathrm{Ni}$ and $\mathrm{Zn}$ were significantly ( $p$ $<0.0001$ ) more abundant (3.3- and 20-fold, respectively) in cells from the anticyclonic eddy compared to cells from the other two eddies. Like $\mathrm{P}$, cellular $\mathrm{Mn}$ and $\mathrm{Fe}$ were both highest in cells from the mode-water eddy. This effect was larger for $\mathrm{Fe}$ (1.8-fold) than Mn (1.5-fold), but the 
Light

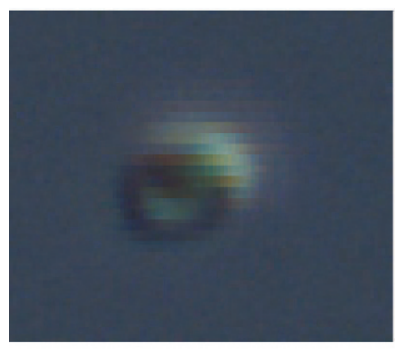

Epi

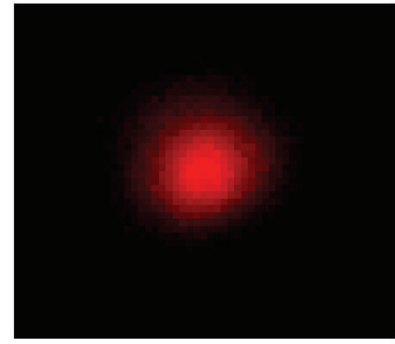

$\mathrm{P}$

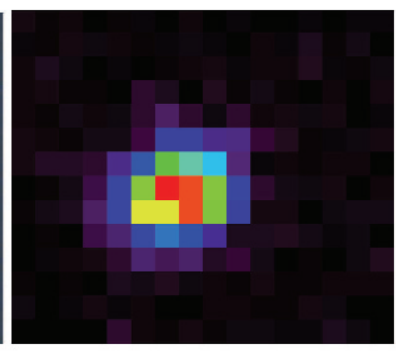

$\mathrm{Fe}$

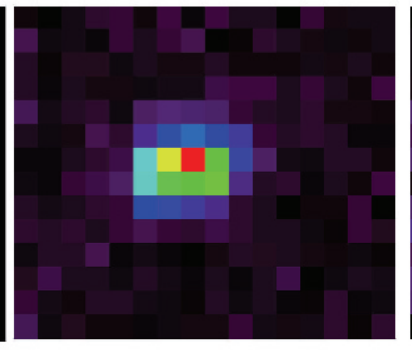

$1 \mu \mathrm{m}$
S

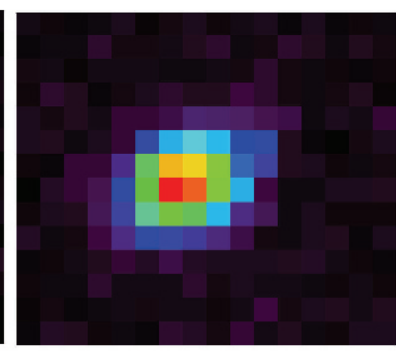

$\mathrm{Ni}$

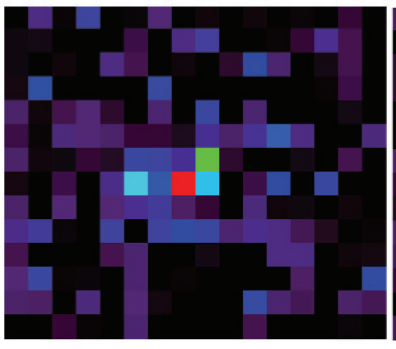

$\mathrm{Mn}$

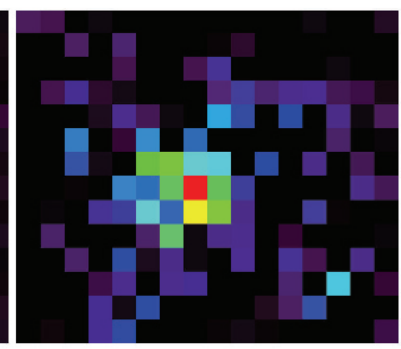

$\mathrm{Zn}$

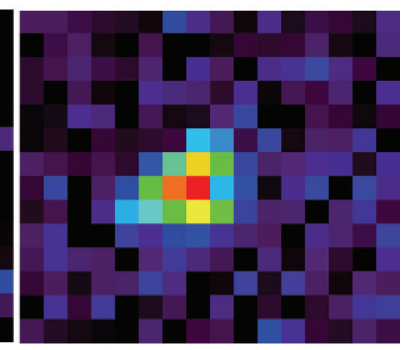

Fig. 4. Light, epifluorescence (Epi), and SXRF P, S, Mn, Fe, Ni, and Zn false-color element maps of a Synechococcus cell collected from a mode-water eddy in the Sargasso Sea. The scale bar indicates $1 \mu \mathrm{m}$.

differences were not statistically significant at the $p<0.05$ level $(p=0.0525)$ because of higher variance in the quotas of this metal. Manganese quotas, however, were significantly different $(p=0.0016)$ between eddies. Unlike P, cellular quotas of the biomass proxy $\mathrm{S}$ did not vary significantly between the eddies $(p=0.0591)$. Sampling depth was also included as an effect in the ANOVA, and significant differences between the elemental quotas of cells collected from $10 \mathrm{~m}$ and the DCM were observed for $\mathrm{S}(p$ $=0.0028)$ and $\mathrm{Ni}(p=0.0146)$. For both elements, leastsquare geometric mean quotas were approximately $80 \%$ higher in surface waters compared to the DCM (Fig. 6). For the other elements, depth effects varied between eddies, precluding statistically significant trends. Geometric mean P quotas appeared constant with depth, while Mn quotas were higher in the DCM at the cyclonic eddy but higher in the surface at the anticyclone (Table 2). Contrasting this, geometric mean $\mathrm{Fe}$ and $\mathrm{Zn}$ quotas were higher in the surface at the cyclonic eddy but higher in the DCM at the anticyclone.
The cyclonic eddy was sampled on three separate occasions during the cruise using a drifting sediment-trap array as a Lagrangian point of reference, thereby allowing us to test for short-term temporal changes in elemental quotas within a single eddy. Significant differences in cellular quotas over the three sampling time points were observed for $\mathrm{P}$ and $\mathrm{Zn}$; the other elements did not vary significantly over time. Least-square geometric mean $\mathrm{P}$ and $\mathrm{Zn}$ cellular quotas at the three time points are plotted in Fig. 7. Cell quotas of both elements decreased between 06 July and 10 July and were then unchanged on 11 July. Cellular P showed relatively small changes, decreasing from 31 amol cell ${ }^{-1}$ on 06 July to approximately 21 amol cell $^{-1}$ on 10 and 11 July. Cellular Zn presented a much larger shift, decreasing eightfold from $226 \mathrm{zmol} \mathrm{cell}^{-1}$ on 06 July to $27-29 \mathrm{zmol}^{\text {cell }}{ }^{-1}$ on 10 and $11 \mathrm{July}$. Although cellular $\mathrm{Zn}$ quotas were clearly elevated in the cyclonic eddy at the first sampling (06 July), they were still less than half the value of the cellular $\mathrm{Zn}$ quotas in the anticyclonic eddy. Some temporal variation is also observed in the concen-

Table 2. Geometric mean element quotas ( $\pm \mathrm{SE})$ of $\mathrm{P}, \mathrm{S}, \mathrm{Mn}, \mathrm{Fe}, \mathrm{Ni}$, and $\mathrm{Zn}$ in Synechococcus collected from two depths (10 $\mathrm{m}$ and $\mathrm{DCM})$ at three mesoscale eddies in the Sargasso Sea. The $\mathrm{P}$ and $\mathrm{S}$ quotas are presented as attomol $\left(10^{-18}\right)$ cell ${ }^{-1}$, and the metal quotas are presented as zeptomole $\left(10^{-21}\right)$ cell $^{-1}$. nd $=$ not determined.

\begin{tabular}{lcccccccc}
\hline \hline & & $n$ & $\mathrm{P}$ & $\mathrm{S}$ & $\mathrm{Mn}$ & $\mathrm{Fe}$ & $\mathrm{Ni}$ \\
\hline Cyclonic & $10 \mathrm{~m}$ & 27 & $25.1 \pm 2.0$ & $79.2 \pm 12.4$ & $8.3 \pm 1.8$ & $158 \pm 47.8$ & $31.6 \pm 6.6$ & $57.5 \pm 13.6$ \\
& $\mathrm{DCM}$ & 35 & $20.0 \pm 1.8$ & $35.0 \pm 5.5$ & $12.3 \pm 2.6$ & $80.9 \pm 16.1$ & $19.2 \pm 4.5$ & $24.2 \pm 4.5$ \\
Anticyclonic & $10 \mathrm{~m}$ & 10 & $28.1 \pm 7.2$ & $73.8 \pm 19.1$ & $27.1 \pm 7.6$ & $87.2 \pm 26.8$ & $149 \pm 47.5$ & $110 \pm 29.6$ \\
& $\mathrm{DCM}$ & 27 & $21.8 \pm 3.3$ & $64.6 \pm 12.7$ & $16.7 \pm 3.2$ & $153 \pm 31.3$ & $63.9 \pm 16.9$ & $1138 \pm 499$ \\
Mode-water & $10 \mathrm{~m}$ & 0 & nd & nd & nd & nd & nd & nd \\
& $\mathrm{DCM}$ & 19 & $50.8 \pm 10.2$ & $63.1 \pm 13.8$ & $28.8 \pm 5.5$ & $224 \pm 38.6$ & $22.0 \pm 2.2$ & $23.6 \pm 4.6$ \\
\hline
\end{tabular}




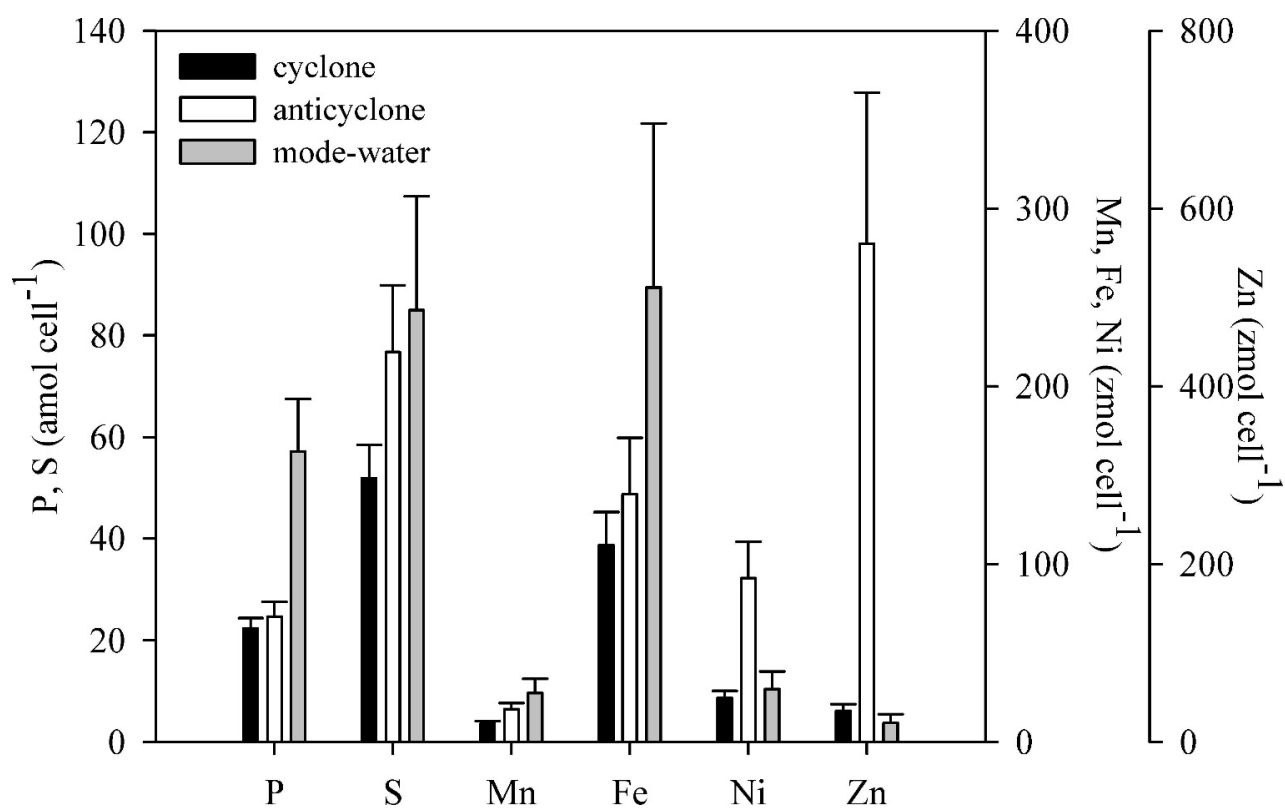

Fig. 5. Least-square geometric mean $( \pm \mathrm{SE}) \mathrm{P}, \mathrm{S}, \mathrm{Mn}, \mathrm{Fe}, \mathrm{Ni}$, and $\mathrm{Zn}$ quotas of individual Synechococcus cells collected from three different mesoscale eddies in the Sargasso Sea as measured with SXRF. The $\mathrm{P}$ and $\mathrm{S}$ quotas are presented as attomole $\left(10^{-18}\right) \mathrm{cell}^{-1}$, and the metal quotas are presented as zeptomole $\left(10^{-21}\right)$ cell $^{-1}$.

tration of chlorophyll present in the DCM of this eddy. Chlorophyll concentrations in the cyclonic eddy increased approximately $50 \%$ from the first sampling on 06 July to the two subsequent samplings on 10-11 July (Table 1).

Dissolved and particulate element concentrations-Differences are observed in the concentrations of dissolved $\mathrm{Fe}$ $(\mathrm{dFe})$, particulate $\mathrm{Fe}(\mathrm{pFe})$, and particulate $\mathrm{P}(\mathrm{pP})$ between the eddies. Dissolved Fe was highest in the surface waters at all stations, indicating an atmospheric source for this micronutrient (Fig. 8). Surface dFe concentrations were

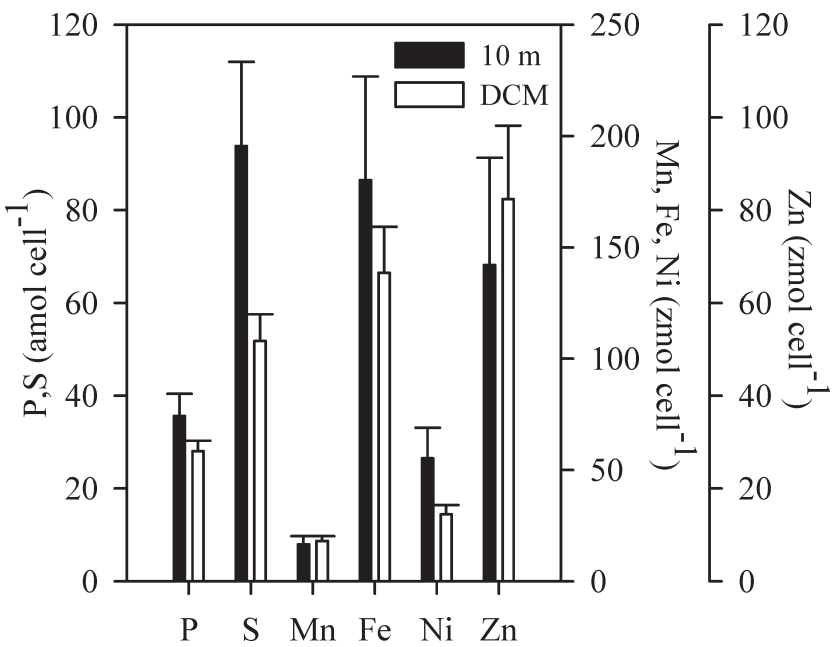

Fig. 6. Least-square geometric mean $( \pm \mathrm{SE}) \mathrm{P}, \mathrm{S}, \mathrm{Mn}, \mathrm{Fe}, \mathrm{Ni}$, and Zn quotas of individual Synechococcus cells collected from two different depths in the Sargasso Sea as measured with SXRF. The $\mathrm{P}$ and $\mathrm{S}$ quotas are presented as attomole $\left(10^{-18}\right)$ cell-1, and the metal quotas are presented as zeptomole $\left(10^{-21}\right)$ cell-1. notably higher in the anticyclonic eddy $(1.0 \mathrm{nmol} \mathrm{L}-1)$ than the other two eddies (ca. $0.5 \mathrm{nmol} \mathrm{L}^{-1}$ ). Furthermore, both the mode-water and the cyclonic eddies were characterized by a $\mathrm{dFe}$ minimum near the top of the DCM; however, this feature was absent in the anticyclonic eddy. Particulate element data also show distinct eddy signatures. Least-square mean $\mathrm{pP}$ was highest in the modewater eddy $\left(11.6 \mathrm{nmol} \mathrm{L}^{-1}\right)$ and lowest in the anticyclone (4.2 $\mathrm{nmol} \mathrm{L}{ }^{-1}$; Fig. 9), matching the trends in chlorophyll

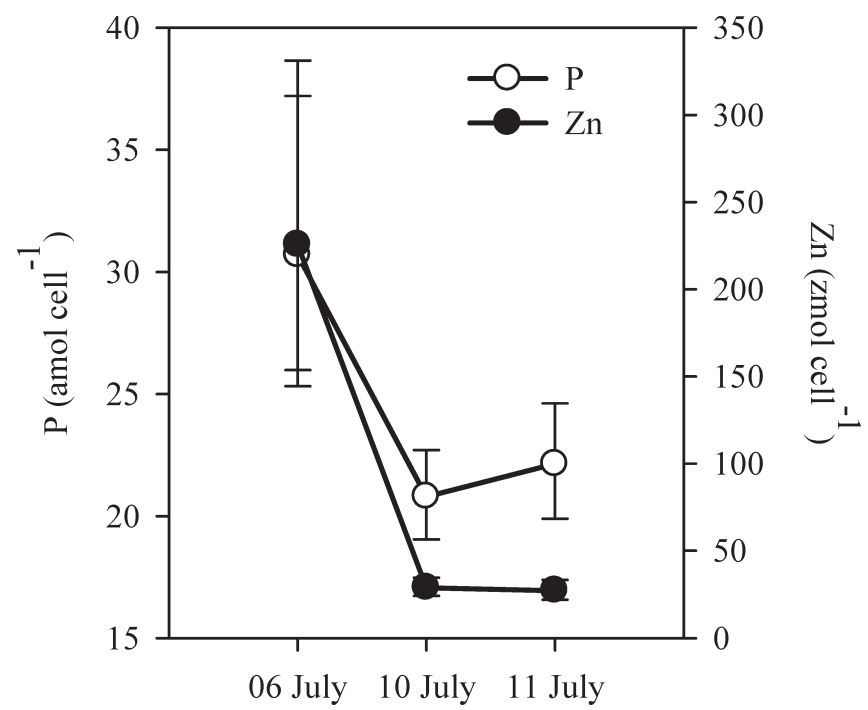

Fig. 7. Least-square geometric mean $( \pm \mathrm{SE}) \mathrm{P}$ and $\mathrm{Zn}$ quotas of Synechococcus cells collected from a cyclonic eddy in the Sargasso Sea on three different days during a cruise in 2007. The P quotas are presented as attomol $\left(10^{-18}\right)$ cell $^{-1}$, and the $\mathrm{Zn}$ quotas are presented as zeptomole $\left(10^{-21}\right)$ cell $^{-1}$. 


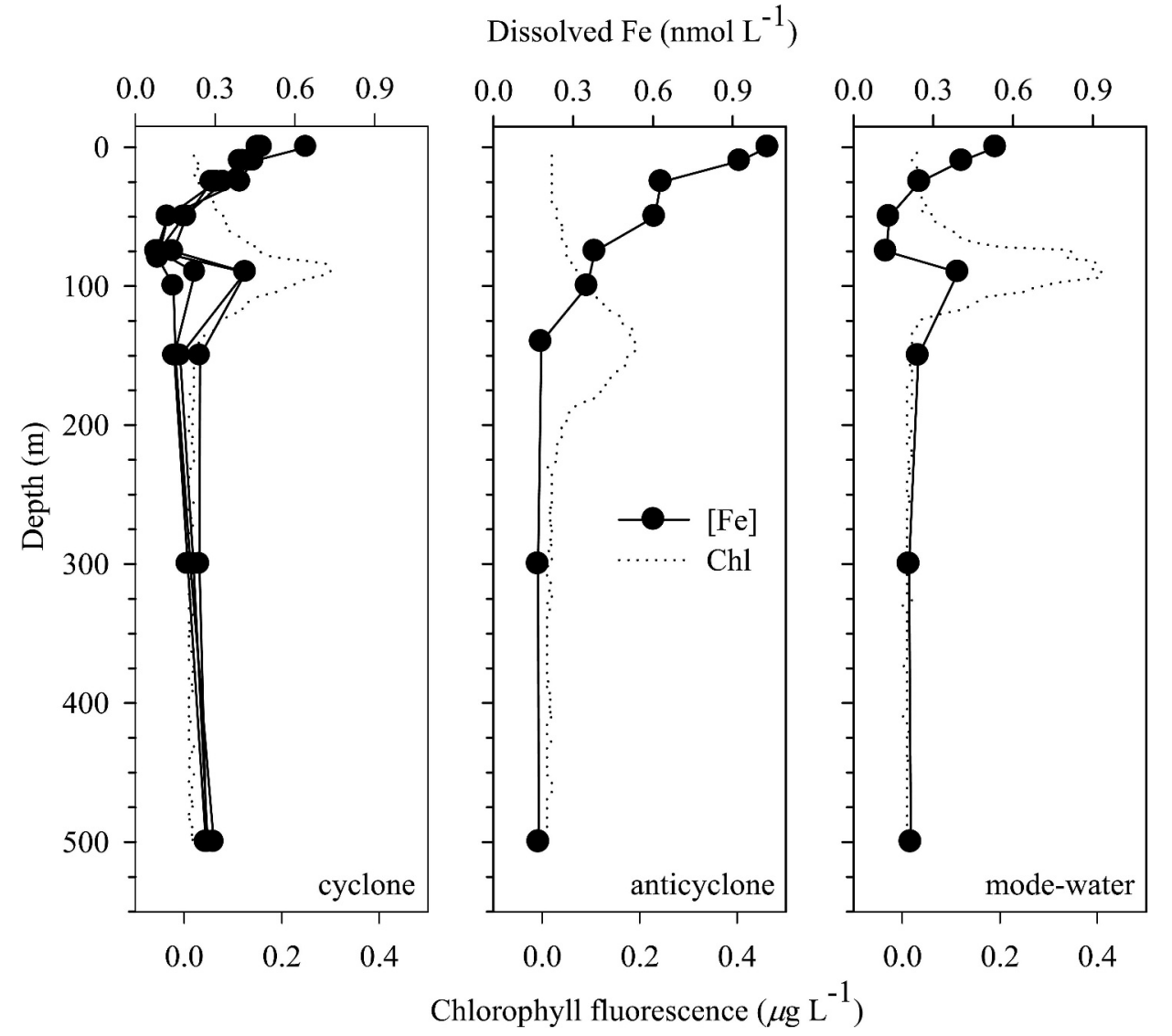

Fig. 8. Vertical concentration profiles of dissolved $\mathrm{Fe}(<0.45 \mu \mathrm{m})$ and chlorophyll fluorescence $\left(\mu \mathrm{g} \mathrm{L}^{-1}\right)$ in the three eddies sampled in this study; four separate profiles were obtained from the cyclonic eddy. Samples were collected, processed, and analyzed following methods of Sedwick et al. (2005).

concentrations. However, like $\mathrm{dFe}, \mathrm{pFe}$ was highest in the anticyclone $\left(1.6 \mathrm{nmol} \mathrm{L}^{-1}\right)$. Particulate $\mathrm{P}$ and $\mathrm{Fe}$ varied between the two sampling depths, with pP $44 \%$ higher in the DCM but $\mathrm{pFe}$ nearly fourfold higher at the surface, clearly reflecting the difference sources for these two bioelements.

\section{Discussion}

This study presents the first measurements of elemental quotas in Synechococcus cells collected from natural waters. We chose to focus on this phytoplankton group for two reasons: to provide fundamental data on the elemental composition of this cosmopolitan and biogeochemically significant organism and to assess the spatial and temporal variability in elemental composition in relation to mesoscale physical circulation and its associated imprint on the geochemical growth environment and cellular physiology. By focusing on a single algal group, we are able to consider variations in measured elemental quotas on a cellular basis (i.e., mole per cell) without the need to normalize metal concentrations to biomass proxies such as $\mathrm{P}$ or $\mathrm{S}$. This is important since cellular quotas of biomass elements such as $\mathrm{P}$ can also be dynamic (Twining et al. 2004a; Baines et al. in press; this study), rendering the interpretation of stoichiometries such as $\mathrm{Fe}: \mathrm{P}$ more challenging than is typically acknowledged. The measurement of cell-specific element quotas allows us to examine simultaneous variations in trace metals and cellular biomass components that would be difficult to identify from bulk stoichiometric analysis. Furthermore, the ubiquitous presence of Synechococcus in the Sargasso Sea makes this organism a useful indicator for assessing the response of phytoplankton to physical and chemical environmental gradients.

Elemental composition and identity of the target cellsTaxonomic identification of picoplankton is challenging because of their small size, which lies at the lower limits of light microscopy; however, there are several lines of evidence indicating that the target cells examined in this study were Synechococcus. Visual examination of the target cells mounted on transmission electron microscopy grids in comparison to cells from the same water samples mounted on black polycarbonate filters indicate that the target cells were of the correct size (length $\sim 1.2 \mu \mathrm{m}$ ), shape (rods), and color (orange fluorescence under blue excitation) for Synechococcus (Fig. 4). These are standard metrics used by oceanographers to identify Synechococcus cells by either microscopy or flow cytometry 
Eddy comparison

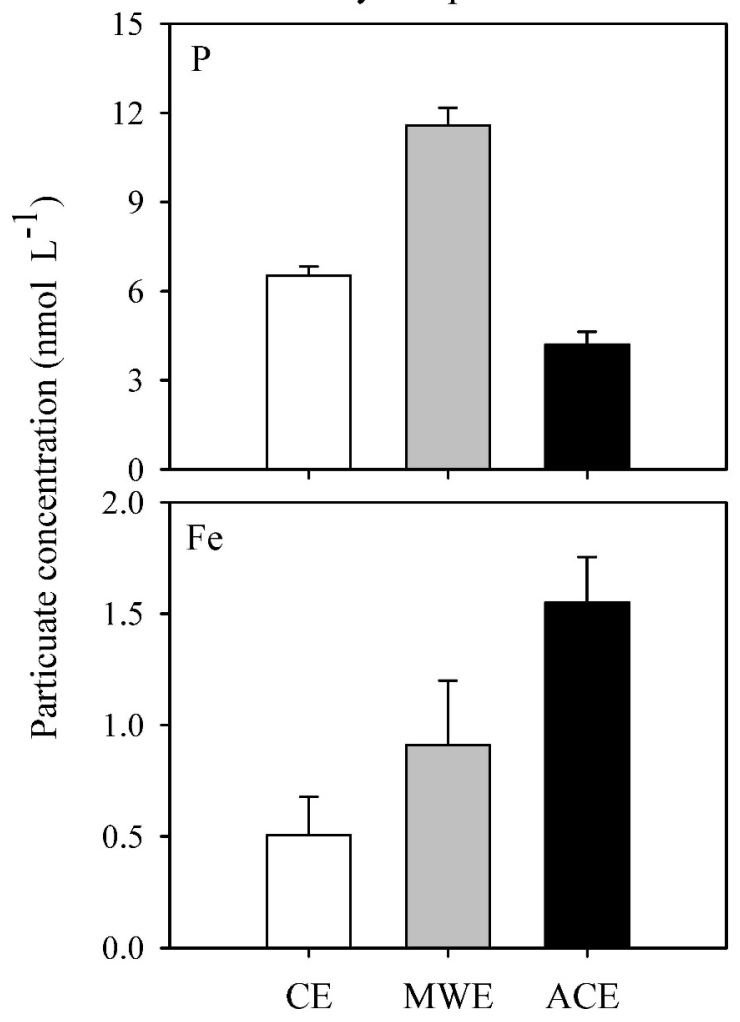

Depth comparison
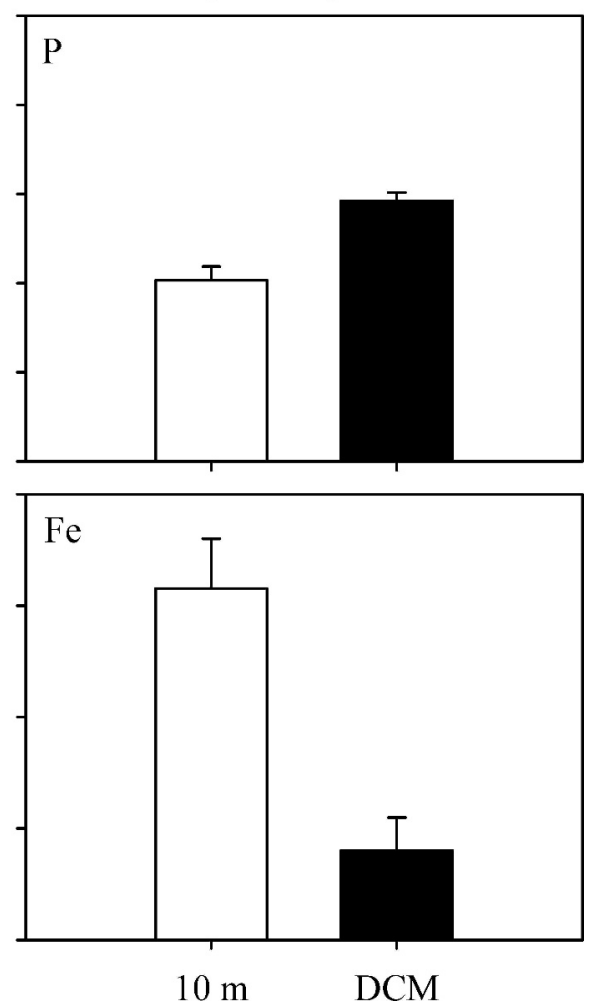

Fig. 9. Least-square mean $( \pm \mathrm{SE}) \mathrm{P}$ and Fe concentrations for particulate material $(>0.6 \mu \mathrm{m})$ collected from two different depths $(10 \mathrm{~m}$ and deep chlorophyll maximum $[\mathrm{DCM}]$ ) within cyclonic (CE), mode-water (MWE), and anticyclonic (ACE) eddies the Sargasso Sea.

(Olson et al. 1990b; DuRand et al. 2001). The process of mounting cells onto TEM grids is not quantitative because cells may be lost during rinsing; however, the target cells appeared similar to cells enumerated on black polycarbonate filters that were present at concentrations $\left(\sim 10,000\right.$ cells $\left.\mathrm{mL}^{-1}\right)$ typical of Synechococcus in the Sargasso Sea; such cell concentrations are likely too low to be Prochlorococcus and too high to be picoeukaryotes (DuRand et al. 2001).

The cellular $\mathrm{P}$ and $\mathrm{S}$ quotas measured for our target cells closely match those reported for cultured Synechococcus strains isolated from the Sargasso Sea. Bertilsson et al. (2003) measured P quotas of $15-108$ amol cell-1 for Plimited and P-replete strains of cultures WH8012 and WH8013, isolated from the Sargasso Sea, whereas we measured mean $\mathrm{P}$ quotas of 22,25 , and $57 \mathrm{amol} \mathrm{cell}^{-1}$ in cells collected from the three eddies. Heldal et al. (2003) report similar P quotas of 71-116 amol cell ${ }^{-1}$ in five Preplete Synechococcus cultures. In contrast, the reported $\mathrm{P}$ quotas of cultured Prochlorococcus cells are typically lower (8-32 amol cell ${ }^{-1}$; Bertilsson et al. 2003; Heldal et al. 2003). In addition, the mean Synechococcus $\mathrm{S}$ quota that was measured by Heldal et al. (2003) with an electron microprobe (72 amol cell-1) is similar to that measured in our target cells (52-85 amol cell $\left.{ }^{-1}\right)$. Therefore, the morphology, abundance, and elemental composition of the target cells examined in this study are wholly consistent with the Synechococcus group.
The Fe quotas measured for the target cells also fall within the broad range of quotas reported for Synechococcus. Timmermans et al. (2005) report an Fe quota for nutrient-replete Synechococcus (strain CCMP 839) of $1.6 \mathrm{zmol}$ cell $^{-1}$, which is two orders of magnitude below the values we have measured. However, the $\mathrm{Fe}: \mathrm{C}$ ratios reported in that study $\left(\sim 5 \mathrm{nmol} \mathrm{mol} \mathrm{C}^{-1}\right)$ are nearly 1000 fold below the lowest Fe quotas measured in eukaryotic phytoplankton (Sunda et al. 1991; Maldonado and Price 1996; Marchetti et al. 2006). Cellular Fe quotas that are more consistent with our measurements are reported by Wilhelm and Trick (1995; strain PCC 7002) and Kudo and Harrison (1997; strain CCMP 1334); both studies yielded Fe quotas of approximately $400 \mathrm{zmol} \mathrm{cell}^{-1}$ in Fe-limited Synechococcus cultures, which are approximately twice the highest $\mathrm{Fe}$ quotas that we measured in field-collected cells (224 zmol cell ${ }^{-1}$ in the mode-water eddy). This difference is likely insignificant, given the very different approaches involved in estimating these cellular quotas (bulk particle measurement by Kudo and Harrison; steady-state chemostat growth calculations by Wilhelm and Trick). The location from which the strain was isolated does not appear to have a strong effect, as the strains used by Timmermans et al. and Kudo and Harrison were both isolated from the Sargasso Sea.

Few published data are available on the $\mathrm{Mn}, \mathrm{Ni}$, or $\mathrm{Zn}$ content of Synechococcus for comparison. Dupont et al. (2008) report Ni quotas for two cultured strains (including 
one isolated from the Sargasso Sea) ranging from approximately 1 to $100 \mathrm{zmol}_{\text {cell }}{ }^{-1}$ over a gradient of free ionic Ni concentrations. These quotas bracket the mean quotas reported here for the Sargasso Sea, providing further evidence that the target cells were Synechococcus. The cells analyzed in this study do not appear to have been $\mathrm{Ni}$ limited, as their Ni quotas were well above the minimum quotas reported by Dupont et al. (2008).

While we are reasonably confident that the target cells analyzed are from the Synechococcus genus, this group comprises a diverse assemblage of species, with strains varying in their genetic and biochemical composition. For example, Synechococcus strains from coastal environments appear to have a greater ability to accumulate and store $\mathrm{Fe}$ (Palenik et al. 2006), and they appear to have correspondingly higher Fe requirements as well (Brand 1991).

Individual strains isolated from the same environment can also differ. The isolates WH8012 and WH8103 were both isolated from the Sargasso Sea and both have rod-like morphology, but the two strains differ in their motility and their elemental content (Waterbury et al. 1986; Rocap et al. 2002; Bertilsson et al. 2003). Phosphorus quotas of cells grown under $\mathrm{P}$ limitation range approximately twofold between the strains (15-26 amol cell ${ }^{-1}$; Bertilsson et al. 2003). Dupont et al. (2008) found Ni quotas to vary between Synechococcus strains WH8102 and CC9311, particularly when grown on nitrate. The size, shape, pigmentation, and elemental composition of the cells analyzed in this study are all characteristic of Synechococcus cells; however, it is not known whether the cells represent the same strain. It is possible that the different eddies contained unique strains or that each eddy had multiple populations of Synechococcus. Depth-related differences could also be caused by the presence of different strains. This cannot be addressed without genetic analyses of the individual analyzed cells, which would preclude elemental analysis.

Intereddy differences in elemental quotas-Synechococcus element quotas varied significantly between the three eddies sampled, and associated variations in cell physiology may reflect differences in nutrient supply between the eddies. Mode-water eddies result in a shoaling of isopycnals and entrainment of nutrient-rich waters from below the euphotic zone (McNeil et al. 1999). Previous work has demonstrated that both $\mathrm{N}$ and $\mathrm{P}$ can be introduced into surface waters through this mechanism (Letelier et al. 2000; Benitez-Nelson et al. 2007), which can be enhanced by eddy-wind interactions (McGillicuddy et al. 2007). The rapid uptake of nutrients by cells makes it difficult to identify such vertical resupply via ship-based bottle sampling (McGillicuddy et al. 1998; McNeil et al. 1999), although the nutrient profiles do show higher concentrations of nitrate and phosphate below the DCM in the mode-water and cyclonic eddies (Fig. 3). This enhanced macronutrient supply resulted not only in greater phytoplankton biomass, as measured by chlorophyll and particulate $\mathrm{P}$, but also in higher $\mathrm{P}$ quotas than in cells from the other eddies. Studies in the tropical and subtropical North Atlantic have observed that the avail- ability of $\mathrm{P}$, in combination with $\mathrm{N}$, can affect the growth and physiology of Synechococcus (Davey et al. 2008; Moore et al. 2008). The measured phosphorus quotas in cells from the cyclonic eddy were similar to those of Plimited cells in culture, whereas the $\mathrm{P}$ quotas in cells from the mode-water eddy were more comparable to those of Preplete cultured cells, which further suggests that greater availability of $\mathrm{P}$ in the mode-water eddy was influencing the composition and physiology of the resident cells.

The observed eddy-specific trends in cellular Zn quotas are also consistent with differences in $\mathrm{P}$ supply to the eddies. Zinc is required as a cofactor in alkaline phosphatase, a metalloenzyme that cleaves phosphomonoester bonds and enables phytoplankton to utilize dissolved organic phosphorus (DOP) substrates when inorganic orthophosphate concentrations are low (Cembella et al. 1984). Alkaline phosphatase activities in cultured phytoplankton and natural communities can be limited by $\mathrm{Zn}$ availability (Shaked et al. 2006) and dissolved Zn concentrations in the western North Atlantic Ocean are drawn down to very low levels south of $38^{\circ} \mathrm{N}$, where elevated chlorophyll-normalized alkaline phosphatase activities have been observed (Jakuba et al. 2008). The supply of inorganic P from below the euphotic zone was weakest in the anticyclonic eddy as a result of isopycnal deepening, and the in situ fluorescence profiles from the anticyclone reveal a chlorophyll maximum that is considerably deeper and weaker than in the cyclonic and mode-water eddies (Fig. 2). Presumably as a result of these conditions, $\mathrm{Zn}$ quotas in the anticyclone were approximately 20 -fold higher than in cells from the other two eddies. The highest $\mathrm{Zn}$ quotas were in cells collected from the DCM of the anticyclone. It is likely that cells in the anticyclonic eddy were accumulating $\mathrm{Zn}$ in order to support the assimilation of DOP, thus resulting in a remarkable shift in cellular elemental composition. Interestingly, Lomas et al. (2004) report little expression of alkaline phosphatase activity in coccoid cyanobacteria from the Sargasso Sea, although these authors noted that their labeling protocol was not optimized for cyanobacteria. Spatial and/or temporal variability in oceanographic conditions and phytoplankton physiology may also explain their contrasting results.

The spatial trends in cellular Ni quotas and dissolved nitrate concentrations are analogous to those for $\mathrm{Zn}$ and phosphate, respectively, suggesting a similar linkage between these nutrients. Nickel is thought to be incorporated primarily in the enzyme urease, which is used by cells to utilize the dissolved organic nitrogen compound urea (Oliveira and Antia 1984; Collier et al. 1999; Dupont et al. 2008). Cyanobacteria may also express a Ni-based form of superoxide dismutase (Palenik et al. 2003), but the quantitative importance of this enzyme to the total cell quota is not yet known. Given that inorganic $\mathrm{N}$ availability in the euphotic zone was lowest in the anticyclonic eddy, cells may have been assimilating organic $\mathrm{N}$ substrates, which would have accordingly required them to increase cellular Ni quotas. Indeed, Synechococcus $\mathrm{Ni}$ quotas were approximately three- to fourfold higher in the anticyclone compared to the other two eddies. Previous work has shown a significant affinity for urea by phytoplankton in 
the Sargasso Sea (Price and Harrison 1988), and reduced N substrates may be particularly important for cyanobacteria in these waters (Casey et al. 2007).

Less pronounced spatial differences were observed in the cellular $\mathrm{Fe}$ quotas despite substantial eddy-related differences in $\mathrm{dFe}$ and $\mathrm{pFe}$ concentrations. Iron quotas were highest in cells from the mode-water eddy; however, euphotic zone $\mathrm{dFe}$ and $\mathrm{pFe}$ concentrations were generally highest in the anticyclonic eddy. The anticyclonic eddy was characterized by elevated surface Fe concentrations, which are thought to reflect greater atmospheric Fe inputs in its source region to the south of our study area, and the absence of pronounced subsurface minima or maxima in dissolved $\mathrm{Fe}$, which is likely related to the weak, deep subsurface fluorescence maximum observed in this feature (Fig. 2). As noted previously, the growth of cells in this eddy may have been limited or stressed by macronutrient deficiencies. Growth rates slowed by macronutrient availability could allow cellular Fe to reach replete levels despite relatively low ambient levels of dissolved $\mathrm{Fe}$. Indeed, shipboard bioassay experiments conducted during the cruise produced no clear evidence of phytoplankton $\mathrm{Fe}$ stress within the euphotic zone. Cellular Fe quotas also do not reflect depth-related $\mathrm{Fe}$ gradients. This suggests either that the additional Fe present in the surface waters of the anticyclone was not bioavailable or, more likely, that Synechococcus were already $\mathrm{Fe}$ replete. Additionally, oceanic strains of Synechococcus have reduced Fe storage capability compared to coastal strains (Palenik et al. 2006), so cellular $\mathrm{Fe}$ quotas may be restrained despite excess available $\mathrm{Fe}$ in the water column. Still, it is interesting to note that the highest Fe quotas were observed in the DCM of the mode-water eddy, the sampling location that appears to have had the highest macronutrient supply from underlying waters (cellular $\mathrm{P}$ was enriched here, while cellular $\mathrm{Ni}$ and $\mathrm{Zn}$ were at their lowest levels).

All the samples used in this study were collected from either cyclonic, mode-water, or anticyclonic eddies. Previous work has shown that the biogeochemical conditions within cyclonic eddies are at least qualitatively similar to the mean conditions in the BATS region of the Sargasso Sea. McGillicuddy et al. (2007) report that diatom biomass was much enhanced in a mode-water eddy compared to that within a cyclonic eddy and adjacent intereddy waters. In addition, the phytoplankton community observed in the cyclonic eddy was similar to the mean community observed at the nearby BATS site (McGillicuddy et al. 2007). Although isopycnals are uplifted within cyclonic eddies, wind-induced downwelling in the interior of the eddy may counteract some of the upwelling effects (McGillicuddy et al. 2007). Cells that we sampled from the cyclonic eddy had the lowest cellular concentrations of all elements except $\mathrm{Zn}$, and these quotas may be the most representative of the long-term average condition of cells at the BATS site during summer.

Temporal changes in elemental quotas-The cyclonic eddy was sampled on three different days during the cruise, and some of the cellular elemental quotas varied over this time period. As with the intereddy comparison, the largest temporal changes were observed for the $\mathrm{P}$ and $\mathrm{Zn}$ cell quotas. These two quotas did not vary inversely, which might be expected if $\mathrm{Zn}$ quotas are linked to $\mathrm{P}$ availability, as we have previously suggested. Rather, mean cellular quotas of both elements decreased between 06 July and 10 July and then remained constant on 11 July (Fig. 7). The decrease in cellular $\mathrm{Zn}$ quotas, which was quantitatively greater than the $\mathrm{P}$ quota decrease, may be related to temporal trends in the phytoplankton community as a whole and associated nutrient availability. Based on the in situ fluorescence profiles from our CTD deployments, phytoplankton biomass within the DCM of the cyclonic eddy increased between our first and second sampling of this feature (Table 1). This may reflect an injection of nutrients into the base of the euphotic zone; such an addition of inorganic $\mathrm{P}$ might have alleviated the need for cells to use DOP and thus lowered cellular $\mathrm{Zn}$ requirements. While this scenario is clearly speculative, it does appear that cellular Zn quotas in the DCM vary inversely with Chl fluorescence. The observed eightfold change in cellular Zn quotas also highlights the dynamic nature of cell composition and physiology. As with other oceanographic measurements, cellular elemental quotas may be prone to significant changes over short time scales, and this needs to be kept in mind when interpreting field data.

Depth dependence of elemental quotas-Different depths were sampled in the cyclonic and anticyclonic eddies, which allows us to compare the elemental quotas of cells from different depths at a given location. Both sulfur and $\mathrm{Ni}$ were approximately $80 \%$ higher in cells collected from $10-\mathrm{m}$ depth relative to cells in the DCM. Although it is difficult to assess whether these compositional shifts have a common biochemical basis, we note that oxidative stress from sunlight and reactive oxygen species produced by photochemical reactions are certainly higher at 10-m depth than within the DCM (Miller et al. 2005). As a result of this, Synechococcus may produce more Ni-based superoxide dismutase near the surface, increasing both $\mathrm{Ni}$ and $\mathrm{S}$. However, the change in cellular S is 1000 -fold larger than the corresponding change in $\mathrm{Ni}$, indicating that other $\mathrm{S}$ containing compounds must also be elevated in the surface cells. Thiol-based antioxidant compounds such as glutathione are also likely to be highly expressed in surface water cells (Dupont et al. 2004), potentially contributing to elevated cellular $\mathrm{S}$ quotas.

No significant differences in cellular $\mathrm{Fe}$ quotas were observed between the shallow and deeper samples when samples from all three eddies were pooled. However, notable depth-related differences in metal quotas were seen in individual eddies. Cells collected from $10 \mathrm{~m}$ in the cyclonic eddy had approximately twofold more $\mathrm{Fe}$ and $\mathrm{Zn}$ than cells collected at the DCM. The opposite trend was found in the anticyclone, where cells from the DCM were relatively enriched in these two metals (Table 2). These do not reflect ambient $\mathrm{dFe}$ concentrations. Subsurface minima in $\mathrm{dFe}$ were observed in the cyclonic and mode-water eddies, but these features occurred immediately above the DCM from which cells were collected (Fig. 9). Thus, the cells at the surface and DCM in the cyclonic eddy were 
Table 3. P-normalized metal stoichiometries $\left(\mathrm{mmol} \mathrm{mol}^{-1}\right)$ for Synechococcus in the Sargasso Sea (this study) compared to stoichiometries in plankton from the Equatorial Pacific (EqPac), North Pacific, and Southern Ocean (S.O.).

\begin{tabular}{llllll}
\hline \hline \multicolumn{1}{c}{ Population } & $\mathrm{Mn}$ & $\mathrm{Fe}$ & $\mathrm{Ni}$ & $\mathrm{Zn}$ & Source \\
\hline Synechococcus in cyclonic eddy & 0.46 & 4.9 & 1.09 & 1.6 & This study \\
Synechococcus in anti-cyclonic eddy & 0.81 & 5.6 & 3.40 & 25.0 & This study \\
Synechococcus in mode-water eddy & 0.57 & 4.4 & 0.43 & 0.46 & This study \\
Picoplankton in EqPac & 0.34 & 1.4 & 0.49 & 0.68 & (Twining et al. in press) \\
Autotrophic flagellates in EqPac & 0.74 & 1.3 & 0.25 & 1.3 & (Twining et al. in press) \\
Autotrophic flagellates in S.O. & 0.16 & 0.54 & 0.16 & 1.4 & (Twining et al. 2004a) \\
Bulk plankton from North Pacific & 0.4 & 5.0 & 0.5 & 1.9 & (Bruland et al. 1991) \\
\hline
\end{tabular}

experiencing similar ambient $\mathrm{dFe}$ concentrations. In the anticyclone, surface $\mathrm{dFe}$ was fivefold higher than at the DCM, also opposite the observed Fe quotas. There are several potential explanations for this; one is that Synechococcus growth was not limited by Fe deficiency in our study region; hence, the cells were regulating their cellular $\mathrm{Fe}$ concentrations accordingly. Alternately, the elevated concentrations of "dissolved" $\mathrm{Fe}(<0.45 \mu \mathrm{m})$ in the surface waters might not have been biologically available because of complexation by organic ligands and/or colloidal size distribution (Cullen et al. 2006; Bergquist et al. 2007). In addition, it is likely that the cells within the DCM (particularly the $140-\mathrm{m} \mathrm{DCM}$ in the anticyclone) require more $\mathrm{Fe}$ to produce additional photopigments; hence, the opposing effects of higher $\mathrm{Fe}$ availability near the surface versus higher physiological cellular Fe requirements at depth may confound our efforts to discern trends in cellular Fe quotas with depth.

Comparison of Synechococcus cellular stoichiometry with phytoplankton from other regions-Although these are the first reported trace metal quotas for natural Synechococcus, metal contents can be normalized to cellular $\mathrm{P}$ for comparison to metal stoichiometries measured in phytoplankton from other oceanic regions (Table 3). The most direct comparison is between the cells analyzed in this study and autotrophic picoplankton collected from surface waters of the equatorial Pacific (EqPac), as both groups were analyzed with SXRF (Twining et al. in press; this study). The EqPac picoplankton were $<2 \mu \mathrm{m}$ in size and are assumed to be cyanobacteria, although the analytical capabilities available during that study did not allow specific confirmation of the cells as Synechococcus. Cellular Mn ratios measured in the Sargasso Sea Synechoccocus are approximately twofold higher than those in EqPac picoplankton, and mean cellular $\mathrm{Fe}$ ratios are elevated approximately threefold in the Sargasso Sea cells. Nickel and $\mathrm{Zn}$ stoichiometries are notably elevated in cells from the cyclonic and anticyclonic eddies, compared to the EqPac cells, whereas the cell stoichiometries of these two metals in cells from the mode-water eddy are comparable to the EqPac picoplankton. Thus, it appears that the metal contents of these cell populations are responding to environmental nutrient concentrations. Dissolved Fe concentrations in the surface waters of the Sargasso Sea are considerably higher than those typical of the EqPac region (Gordon et al. 1997; Sedwick et al. 2005; this study), contributing to the higher cellular $\mathrm{Fe}$ quotas in the Sargasso. However, macronutrient concentrations are relatively low in the Sargasso Sea, raising cellular requirements for metals involved in organic $\mathrm{N}$ and $\mathrm{P}$ utilization. In the mode-water eddy, where nitrate and phosphate supply is enhanced, cellular $\mathrm{Ni}$ and $\mathrm{Zn}$ stoichiometries are comparable to the EqPac region.

The Synechococcus metal stoichiometries can also be compared to those of eukaryotic phytoplankton in the EqPac and Southern Ocean (Table 3). Taking the cyclonic eddy cells as most representative of those in the BATS region, it is apparent that Synechoccocus have notably higher Fe and $\mathrm{Ni}$ contents but similar $\mathrm{Mn}$ and $\mathrm{Zn}$ to the autotrophic flagellates in the other regions. In addition to the possible environmental causes discussed previously, these differences are likely to reflect taxonomic differences in physiology. Cyanobacteria are thought to have higher cellular $\mathrm{Fe}$ requirements than eukaryotic phytoplankton because of the higher relative abundance of photosystem I (Raven 1990). Nickel requirements in this taxa are also likely to be higher as a result of additional Ni requirements associated with the expression of Ni superoxide dismutase (Dupont et al. 2008) and/or utilization of organic N substrates (Casey et al. 2007).

This study presents the first measurements of the cellular quotas of P, S, and trace metals in Synechoccocus collected from the open ocean. While conforming to the broad range of quotas determined from laboratory studies, our results highlight the dynamic responses of phytoplankton elemental composition to physical and chemical environmental gradients. We have documented significant variations in cellular elemental quotas according to different eddy types, sampling depths, and time of sampling. Cells from a modewater eddy were found to be enriched in $\mathrm{P}$ and to a lesser extent $\mathrm{Fe}$, while cells from an anticyclonic eddy were found to contain significantly more $\mathrm{Ni}$ and $\mathrm{Zn}$. We speculate that cells in the nutrient-poor waters of the anticyclonic eddy must rely more heavily on organic $\mathrm{N}$ and $\mathrm{P}$ substrates, thus raising their requirements for these trace metals. Cellular $\mathrm{Fe}$ quotas do not appear to have been influenced by ambient concentrations of dissolved or particulate Fe. Both of these Fe pools were highest in the anticyclone, while $\mathrm{Fe}$ quotas were highest in the mode-water eddy. This may indicate that Aeolian $\mathrm{Fe}$ is not immediately available to cells in the water column or that cells were Fe replete in our study region. In addition, we observed the cellular quotas of $\mathrm{P}$ and $\mathrm{Zn}$ to change significantly over time, potentially mirroring changes in the algal biomass related to nutrient 
availability. Finally, cells collected near the surface had higher Ni and S quotas than cells from the DCM, perhaps reflecting biochemical responses to greater oxidative stress near the sea surface.

Phytoplankton directly link the biogeochemical cycles of trace metals and macronutrients, and their elemental composition may provide an in situ gauge of nutrient availability and environmental conditions experienced by resident phytoplankton. These are the first direct measurements of trace metal quotas or stoichiometries in any phytoplankton group collected from the Atlantic Ocean. Variability is evident on several scales: between ocean basins, between neighboring eddies, and between depths at the same station. This variability provides unique opportunities to test our understanding of phytoplankton physiology and nutrient availability within natural communities of the ocean. In some cases, such as $\mathrm{Ni}$ and $\mathrm{Zn}$ variations observed in the context of varying macronutrient supply, the data conform to our current understanding of biogeochemistry. Other observations, such as the lack of a correlation between dissolved and cellular $\mathrm{Fe}$, demonstrate remaining gaps in our knowledge. In both cases, cellular elemental quota measurements are invaluable for assessing the physiological status and biogeochemical function of phytoplankton groups in the natural environment.

\section{Acknowledgments}

The authors thank Dennis McGillicuddy and Valery Kosnyrev for providing the sea-level altimetry analyses that guided our sampling during the cruise as well as the officers and crew of $\mathrm{R} / \mathrm{V}$ Atlantic Explorer and our colleagues who participated in the FeAST-2 cruise. We thank Stephen Baines for assistance with X-ray fluorescence analyses and for statistical advice. Brandon Bozard, Sara Rauschenberg, and Mike Handley provided assistance with the particulate analyses. The paper was improved by the comments of two anonymous reviewers. This work was supported by grants from the U.S. National Science Foundation (OCE-0527062 and CBET0730061 to B.S.T. and OCE-0550594 to P.N.S.) and by start-up funds from the University of South Carolina to B.S.T. Use of the Advanced Photon Source was supported by the U.S. Department of Energy, Office of Science, Office of Basic Energy Sciences, under contract no. DE-AC02-06CH11357.

\section{References}

Baines, S. B., B. S. Twining, S. Vogt, W. M. Balch, N. S. Fisher, AND D. M. Nelson. In press. Silicification of Equatorial Pacific diatoms exposed to additions of silicic acid and iron. Deep-Sea Res. II.

Benitez-Nelson, C. R., and D. J. McGillicuddy. 2008. Mesoscale physical-biological-biogeochemical linkages in the open ocean: An introduction to the results of the E-Flux and EDDIES programs. Deep-Sea Res. II 55: 1133-1138.

— AND OTHERS. 2007. Mesoscale eddies drive increased silica export in the subtropical Pacific Ocean. Science 316: 1017-1021.

Bergquist, B. A., J. Wu, And E. A. Boyle. 2007. Variability in oceanic dissolved iron is dominated by the colloidal fraction. Geochim. Cosmochim. Acta 71: 2960-2974.

Bertilsson, S., O. Berglund, D. M. Karl, and S. W. Chisholm. 2003. Elemental composition of marine Prochlorococcus and Synechococcus: Implications for the ecological stoichiometry of the sea. Limnology and Oceanography 48: 1721-1731.
BRAND, L. E. 1991. Minimum iron requirements of marine phytoplankton and the implications for the biogeochemical control of new production. Limnol. Oceanogr. 36: 1756-1771.

Bruland, K. W., J. R. Donat, and D. A. Hutchins. 1991. Interactive influences of bioactive trace-metals on biological production in oceanic waters. Limnol. Oceanogr. 36: $1555-1577$.

Casey, J. R., M. W. Lomas, J. Mandecki, and D. E. Walker. 2007. Prochlorococcus contributes to new production in the Sargasso Sea deep chlorophyll maximum. Geophys. Res. Lett. 34: L10604, doi:10.1029/2006GL028725.

Cembella, A. D., N. J. Antia, and P. J. Harrison. 1984. The utilization of inorganic and organic phosphorous compounds as nutrients by eukaryotic microalgae: A multidisciplinary perspective: part 1. CRC Crit. Rev. Microbiol. 10: 317-391.

Collier, J. L., B. Brahamsha, and B. Palenik. 1999. The marine cyanobacterium Synechococcus sp. WH7805 requires urease (urea amidohydrolase, EC 3.5.1.5) to utilize urea as a nitrogen source: Molecular-genetic and biochemical analysis of the enzyme. Microbiology 145: 447-459.

Collier, R., AND J. Edmond. 1984. The trace element geochemistry of marine biogenic particulate matter. Prog. Oceanogr. 13: $113-199$.

Cullen, J. T., M. P. Field, And R. M. Sherrell. 2001. Determination of trace elements in filtered suspended marine particulate material by sector field HR-ICP-MS. J. Anal. At. Spectrom. 16: 1307-1312.

, T. W. Lane, F. M. M. Morel, and R. M. Sherrell. 1999. Modulation of cadmium uptake in phytoplankton by seawater $\mathrm{CO}_{2}$ concentration. Nature 402: 165-167.

Davey, M., G. A. Tarran, M. M. Mills, C. Ridame, R. J. Geider, AND J. LARoche. 2008. Nutrient limitation of picophytoplankton photosynthesis and growth in the tropical North Atlantic. Limnol. Oceanogr. 53: 1722-1733.

DeBaar, H. J. W., M. A. Vanleeuwe, R. Scharek, L. Goeyens, K. M. J. BAKKER, AND P. Fritsche. 1997. Nutrient anomalies in Fragilariopsis kerguelensis blooms, iron deficiency and the nitrate/phosphate ratio (A. C. Redfield) of the Antarctic Ocean. Deep-Sea Res. II 44: 229-260.

Dupont, C. L., K. Barbeau, and B. Palenik. 2008. Ni uptake and limitation in marine Synechococcus strains. Appl. Environ. Microb. 74: 23-31.

, T. J. Goepfert, P. Lo, L. P. Wei, and B. A. Ahner. 2004. Diurnal cycling of glutathione in marine phytoplankton: Field and culture studies. Limnol. Oceanogr. 49: 991-996.

DuRand, M. D., R. J. Olson, and S. W. Chisholm. 2001. Phytoplankton population dynamics at the Bermuda Atlantic Time-series station in the Sargasso Sea. Deep-Sea Res. II 48: 1983-2003.

Gordon, R. M., K. H. Coale, and K. S. Johnson. 1997. Iron distributions in the equatorial Pacific: Implications for new production. Limnol. Oceanogr. 42: 419-431.

Heldal, M., D. J. Scanlan, S. Norland, F. Thingstad, and N. H. MANN. 2003. Elemental composition of single cells of various strains of marine Prochlorococcus and Synechococcus using X-ray microanalysis. Limnol. Oceanogr. 48: 1732-1743.

Hutchins, D. A., AND K. W. BRuland. 1998. Iron-limited diatom growth and $\mathrm{Si}: \mathrm{N}$ uptake ratios in a coastal upwelling regime. Nature 393: 561-564.

Jakuba, R. W., J. W. Moffett, and S. T. Dyhrman. 2008. Evidence for the linked biogeochemical cycling of zinc, cobalt, and phosphorus in the western North Atlantic Ocean. Glob. Biogeochem. Cycles 22: GB4012, doi:10.1029/2007GB003119.

Johnson, K. S., AND others. 2007. Developing standards for dissolved iron in seawater. EOS 88: 131-132, doi.10.1029/ 2007EO110003. 
KNAP, A. H., AND others. 1993. BATS methods manual, version 3. U.S. JGOFS Planning Office.

Kudo, I., AND P. J. HARRISON. 1997. Effect of iron nutrition on the marine cyanobacterium Synechococcus grown on different N sources and irradiances. J. Phycol. 33: 232-240.

Letelier, R. M., D. M. Karl, M. R. Авbott, P. Flament, M. Freitlich, R. Lukas, and T. Strub. 2000. Role of later winter mesoscale events in the biogeochemical variability of the water column of the North Pacific Subtropical Gyre. J. Geophys. Res. 105: 28723-28739.

Lomas, M. W., A. Swain, R. Shelton, and J. W. Ammerman. 2004. Taxonomic variability of phosphorus stress in Sargasso Sea phytoplankton. Limnol. Oceanogr. 49: 2303-2310.

MacisaAc, E. A., and J. G. Stockner. 1993. Enumeration of phototrophic picoplankton by autofluorescence microscopy, p. 187-197. In P. F. Kemp, B. F. Sherr, E. B. Sherr and J. J. Cole [eds.], Handbook of methods in aquatic microbial ecology. CRC Press.

Maldonado, M. T., and N. M. Price. 1996. Influence of $\mathrm{N}$ substrate on $\mathrm{Fe}$ requirements of marine centric diatoms. Mar. Ecol. Prog. Ser. 141: 161-172.

Mann, E. L., N. Ahlgren, J. W. Moffett, and S. W. Chisholm. 2002. Copper toxicity and cyanobacteria ecology in the Sargasso Sea. Limnol. Oceanogr. 47: 976-988.

Marchetti, A., M. T. Maldonado, E. S. Lane, and P. J. HARRISON. 2006. Iron requirements of the pennate diatom Pseudo-nitzschia: Comparison of oceanic (high-nitrate, lowchlorophyll waters) and coastal species. Limnol. Oceanogr. 51: 2092-2101.

Martin, J. H., and G. A. Knauer. 1973. The elemental composition of plankton. Geochim. Cosmochim. Acta 37: 1639-1653.

McGillicuddy, D. J., R. Johnson, D. A. Siegel, A. F. Michaels, N. R. BAtes, AND A. H. KNAP. 1999. Mesoscale variations of biogeochemical properties in the Sargasso Sea. J. Geophys. Res.-Oceans 104: 13381-13394.

—, AND A. R. Robinson. 1997. Eddy-induced nutrient supply and new production in the Sargasso Sea. Deep-Sea Res. I 44: 1427-1450.

— AND OTHERs. 1998. Influence of mesoscale eddies on new production in the Sargasso Sea. Nature 394: 263-266.

$\longrightarrow$, AND OTHERS. 2007. Eddy/wind interactions stimulate extraordinary mid-ocean plankton blooms. Science 316: 1021-1026.

McNeil, J. D., H. W. Jannasch, T. Dickey, D. McGillicuddy, M. Brzezinski, and C. M. Sakamoto. 1999. New chemical, bio-optical and physical observations of upper ocean response to the passage of a mesoscale eddy off Bermuda. J. Geophys. Res.-Oceans 104: 15537-15548.

Miller, G. W., AND others. 2005. Hydrogen peroxide method intercomparison study in seawater. Mar. Chem. 97: 4-13.

Moore, C. M., M. M. Mills, R. Langlois, A. Milne, E. P. Achterberg, J. Laroche, and R. J. Geider. 2008. Relative influence of nitrogen and phosphorus availability on phytoplankton physiology and productivity in the oligotrophic subtropical North Atlantic Ocean. Limnol. Oceanogr. 53: 291-305.

Morel, F. M. M., J. R. Reinfelder, S. B. Roberts, C. P. Chamberlain, J. G. Lee, and D. Yee. 1994. Zinc and carbon co-limitation of marine phytoplankton. Nature 369: 740-742.

Oliveira, L., And N. J. Antia. 1984. Evidence of nickel ion requirement for autotrophic growth of a marine diatom with urea serving as nitrogen source. Br. Phycol. J. 19: 125-134.

Olson, R. J., S. W. Chisholm, E. R. Zettler, M. A. Altabet, AND J. A. Dusenberry. 1990a. Spatial and temporal distributions of prochlorophyte picoplankton in the North Atlantic Ocean. Deep-Sea Res. 37: 1033-1051. size, and distributions of Synechococcus in the North Atlantic and Pacific Oceans. Limnol. Oceanogr. 35: 45-58.

PAlenik, B., AND others. 2003. The genome of a motile marine Synechococcus. Nature 424: 1037-1042.

— AND OTHERS. 2006. Genome sequence of Synechococcus CC9311: Insights into adaptation to a coastal environment. Proc. Natl. Acad. Sci. 103: 13555-13559.

Price, N. M., ANd P. J. Harrison. 1988. Urea uptake by Sargasso Sea phytoplankton: Saturated and in situ uptake rates. DeepSea Res. 35: 1579-1593.

Raven, J. A. 1990. Predictions of Mn and Fe use efficiencies of phototrophic growth as a function of light availability for growth and of $\mathrm{C}$ assimilation pathway. New Phytol. 116: $1-18$.

Rocap, G., D. L. Distel, J. B. Waterbury, and S. W. Chisholm. 2002. Resolution of Prochlorococcus and Synechococcus ecotypes by using $16 \mathrm{~S}-23 \mathrm{~S}$ ribosomal DNA internal transcribed spacer sequences. Appl. Environ. Microb. 68: $1180-1191$.

Saito, M. A., and J. W. Moffett. 2002. Temporal and spatial variability of cobalt in the Atlantic Ocean. Geochim. Cosmochim. Acta 66: 1943-1953.

—, J. W. Moffett, And G. R. Ditullio. 2004. Cobalt and nickel in the Peru upwelling region: A major flux of labile cobalt utilized as a micronutrient. Glob. Biogeochem. Cycles 18: GB4030, doi:10.1029/2003GB002216.

Sedwick, P. N., AND others. 2005. Iron in the Sargasso Sea (Bermuda Atlantic Time-series Study region) during summer: Eolian imprint, spatiotemporal variability, and ecological implications. Glob. Biogeochem. Cycles 19: GB4006, doi:10.1029/2004GB002445.

Shaked, Y., Y. Xu, K. Leblanc, and F. M. M. Morel. 2006. Zinc availability and alkaline phosphatase activity in Emiliania huxleyi: Implications for $\mathrm{Zn}-\mathrm{P}$ co-limitation in the ocean. Limnol. Oceanogr. 51: 299-309.

Sokal, R. R., And F. J. Rohlf. 1995. Biometry. W. H. Freeman and $\mathrm{Co}$.

Steinberg, D. K., C. A. Carlson, N. R. Bates, R. J. Johnson, A. F. Michaels, and A. H. Knap. 2001. Overview of the US JGOFS Bermuda Atlantic Time-series Study (BATS): A decade-scale look at ocean biology and biogeochemistry. Deep-Sea Res. II 48: 1405-1447.

Sunda, W. G., D. G. Swift, and S. A. Huntsman. 1991. Low iron requirement for growth in oceanic phytoplankton. Nature 351: $55-57$.

Timmermans, K. R., B. van der Wagt, M. J. W. Veldhuis, A. Mattman, and H. J. W. de BaAR. 2005. Physiological responses of three species of marine pico-phytoplankton to ammonium, phosphate, iron and light limitation. J. Sea Res. 53: $109-120$.

Twining, B. S., S. B. Baines, J. B. Bozard, S. Vogt, E. A. Walker, AND D. M. Nelson. In press. Metal quotas of plankton in the equatorial Pacific Ocean. Deep-Sea Res. II.

, AND N. S. FISHER. 2004a. Element stoichiometries of individual plankton cells collected during the Southern Ocean Iron Experiment (SOFeX). Limnol. Oceanogr. 49: $2115-2128$.

- - - , AND M. R. LANDRY. 2004b. Cellular iron contents of plankton during the Southern Ocean Iron Experiment (SOFeX). Deep-Sea Res. I 51: 1827-1850.

- - S. Vogt, And M. D. De Jonge. 2008. Exploring ocean biogeochemistry by single-cell microprobe analysis of protist elemental composition. J. Eukaryot. Microbiol. 55: 151-162. 
AND OTHERs. 2003. Quantifying trace elements in individual aquatic protist cells with a synchrotron x-ray fluorescence microprobe. Anal. Chem. 75: 3806-3816.

Vogt, S. 2003. MAPS: A set of software tools for analysis and visualization of 3D X-ray fluorescence data sets. J. Phys. IV 104: 635-638.

Waterbury, J. B., S. W. Watson, F. W. Valois, and D. G. FRANKS. 1986. Biological and ecological characterization of the marine unicellular cyanobacterium Synechococcus. In T. Platt and W. Li [eds.], Photosynthetic picoplankton. Can. J. Fish. Aquat. Sci. Bull. 214: 71-120.
Wilhelm, S. W., And C. G. Trick. 1995. Physiological profiles of Synechococcus (Cyanophyceae) in iron-limiting continuous cultures. J. Phycol. 31: 79-85.

Associate editor: John Albert Raven

Received: 05 June 2009 Accepted: 16 October 2009 Amended: 27 October 2009 